\title{
Low coverage sequencing for repetitive DNA analysis in Passiflora edulis Sims: citogenomic characterization of transposable elements and satellite DNA
}

Vanessa Carvalho Cayres Pamponét ${ }^{1}$, Margarete Magalhães Souza ${ }^{1 *}$, Gonçalo Santos Silva ${ }^{1}$, Fabienne Micheli ${ }^{1,2}$, Cláusio Antônio Ferreira de Melo ${ }^{1}$, Sarah Gomes de Oliveira ${ }^{3}$, Eduardo Almeida Costa ${ }^{4}$ and Ronan Xavier Corrêa ${ }^{1}$

\begin{abstract}
Background: The cytogenomic study of repetitive regions is fundamental for the understanding of morphofunctional mechanisms and genome evolution. Passiflora edulis a species of relevant agronomic value, this work had its genome sequenced by next generation sequencing and bioinformatics analysis performed by RepeatExplorer pipeline. The clusters allowed the identification and characterization of repetitive elements (predominant contributors to most plant genomes). The aim of this study was to identify, characterize and map the repetitive DNA of $P$. edulis, providing important cytogenomic markers, especially sequences associated with the centromere.

Results: Three clusters of satellite DNAs (69, 118 and 207) and seven clusters of Long Terminal Repeat (LTR) retrotransposons of the superfamilies Ty1/Copy and Ty3/Gypsy and families Angela, Athila, Chromovirus and MaximusSire $(6,11,36,43,86,94$ and 135) were characterized and analyzed. The chromosome mapping of satellite DNAs showed two hybridization sites co-located in the 5 S rDNA region (PeSat_1), subterminal hybridizations (PeSat_3) and hybridization in four sites, co-located in the $45 \mathrm{~S}$ rDNA region (PeSat_2). Most of the retroelements hybridizations showed signals scattered in the chromosomes, diverging in abundance, and only the cluster 6 presented pericentromeric regions marking. No satellite DNAs and retroelement associated with centromere was observed.

Conclusion: P. edulis has a highly repetitive genome, with the predominance of Ty3/Gypsy LTR retrotransposon. The satellite DNAs and LTR retrotransposon characterized are promising markers for investigation of the evolutionary patterns and genetic distinction of species and hybrids of Passiflora.
\end{abstract}

Keywords: Chromosome mapping, LTR retrotransposons, RepeatExplorer, in tandem repetitive DNA, Molecular cytogenetics, FISH

\section{Background}

The Passiflora edulis Sims species (Passifloraceae A. L. de Jussieu ex Kunth), also known as sour passion fruit, is original of tropical climate. Brazil is considered one of the most important centers for genetic diversity of Passiflora L., with over than 137 indigenous and approximately 85 endemic species [1-3]. Passion fruit cultures have a high agronomic value due to the production of in

\footnotetext{
* Correspondence: souzamagg@yahoo.com.br

${ }^{1}$ Departamento de Ciências Biológicas, Universidade Estadual de Santa Cruz (UESC), km 16, Salobrinho, Ilhéus, Bahia CEP 45662-900, Brazil

Full list of author information is available at the end of the article
}

natura fruit and juices consumption, which reflects the potential consumer market $[4,5]$. The last survey for agricultural production realized in 2015 by the Brazilian Institute of Geography and Statistics (IBGE) with reference to the period between 2007 and 2013, placed Brazil as the world's largest producer and consumer of passion fruit, and the state of Bahia as the largest producer in the country [6]. In addition to Brazil being the main consumer market, the sour passion fruit exportation is booming, representing an important generator of foreign exchange $[4,5]$. 
Plant genomes have a substantial portion of repetitive DNA sequences, which can represent more than $80 \%$ of the genome size in certain plant species, as observed in wheat (Triticum aestivum L.) and maize (Zea mays L.) [7, 8]. Repetitive DNA can be classified by its structure and location, including: (i) in tandem repeats or satellite DNA (SatDNA) and (ii) scattered sequences (transposable elements-TEs) [9-11]. In tandem repeated DNAs represent the main component of heterochromatic regions, and can be associated with specific functions in the chromosome, such as centromeres and telomeres. They can be classified based on the repeated unit (monomer), and cluster repetition sizes. Considering the differences in the size of the repeating units, they are classified as microsatellites ( 1 to 5 base pairs - pb), minisatellites (up to $100 \mathrm{pb}$ ) and satellites (hundreds to thousands of pb). Micro- and minisatellites can be found throughout the genome (rarely associated to gene regions) and are the main components of telomeres; while satellites are more frequent observed in centromere and subtelomere regions [12]. Despite the many studies focusing on SatDNA, little is known about their functions [8], in contrast to studies involving ribosomal DNA (rDNA), which consist of in tandem moderated repeats, and represent sequences preserved between species and have well-defined functions [13].

Since their discovery by McClintock in 1948 [14], TEs have been subject of many studies and new knowledge continues to be generated. It is currently known that TEs can represent $80 \%$ of genomic DNA in plants; as observed in wheat, where TEs represent $68 \%$ of the genome [7]. TEs are classified based on enzymology, structural similarities and sequence relationships $[15,16]$. In eukaryotic genomes the TEs belongs to two types: a) Retrotransposons, which move in the genome by a reverse transcription of an RNA intermediate, producing a new copy in every replication cycle; and b) Transposons, DNAs that move directly within the genome by a mechanism called "cut-and-paste" [16]. Retrotransposons can be divided into two large groups: Long Terminal Repeats (LTR) retrotransposons, and non-LTR retrotransposons [17]. In general, elements with LTR are more abundant in plants, and elements without LTR and are more frequent in mammals [18, 19]. Our study focused on LTR-retrotransposon, which is characterized by an internal region formed of gag genes (group-specific antigen, encoding structural proteins similar to the viral capsid), pol genes (polyprotein, encoding the catalytic protein integrase (INT)), reverse transcriptase (RT) and RNA$\mathrm{seH}$ ( $\mathrm{RH}$, required for replication), and long terminal repeats [20]. The Ty1/Copy superfamily is the most abundant LTR retrotransposons within plant genomes, differing in the preserved domain of RT genes and in the position of the INT domain within the pol complex [21].
Regarding to their chromosome position, the retrotransposons may be present in every chromosome, also observed in centromeric and pericentromeric regions [22]. Retrotransposons associated with the centromere have been found in wheat [23], rice [24] and sugarcane [25]. Mobility and amplification of retrotransposons continuously generate mutations, therefore a source of genome diversity, besides acting in genetic regulation [26, 27]. Thus, the repetitive DNA sequences that are so abundant in plants can be responsible for their genome variation, which may influence the evolutionary distances between species $[8,28]$. Centromere region (pCEN38) probes were used in evolutionary studies in sorghum (Sorghum bicolor (L.) Moench), demonstrating that sorghum and sugarcane share the same ancestor [29]. In the microalga Tisochrysis lutea, families found of mobile TEs were among the three most expressed genes detected in a transcriptional study, important for evolutionary study in microalgae [30].

The amount of sequences of Passiflora edulis deposited in public databases is relatively small, limiting the knowledge about its genome [31]. Genomic studies of agricultural crops such as passion fruit are needed to guide the gene manipulation, and can help breeding programs to improve their quality and productivity [32]. Expanding the Passiflora genomic studies is important to enhance the knowledge about the structure, function and regulation of the genome, helping the understanding of evolutionary, physiological and morphological aspects.

The Molecular Cytogenetics studies, through the Fluorescent In Situ Hybridization (FISH) technique have allowed the localization of genes and repetitive DNA sequences, allowing the detailed investigation of chromosomal structure [33, 34]. This tool has led to important advances on plant cytogenetics, as well as the verification of the genetic stability during cross-breeding processes, the genitors selection (by selecting plants containing genetic alterations associated with the characteristics of interest), and the monitoring of the amount of genetic material generated by interspecific crossings [35]. In addition, FISH also contribute to analyses of intergenomic pairing in hybrids, and the use of probes containing repetitive elements to detect heterochromatic regions or large number of repetitions that are particularly useful for mapping and evolutionary studies in plant genomes [36].

The construction of linkage maps in Passiflora [37, 38] will allow gene sequences of agronomic importance to be located on chromosomes using FISH, integrating cytogenetic and genetic maps, as performed in Lotus japonicus L. [39]. Chromosome rearrangements can be identified by changing the location of chromosomal regions, such as centromeric regions. The effects of chromosomal rearrangements can be beneficial, and may result either in characteristics of interest, or can lead to 
undesirable characteristics, such as plant sterility [40]. The identification and cytogenomic characterization of repetitive DNA in sour passion fruit using FISH may enable the analysis of genomic changes in plants. These sequences might be used as cytogenomic markers to analyze karyotype alterations originated from loci movement. These repositioning are often observed in centromeric regions, as verified in evolutionary studies with cucumbers and melons, and in similar species belonging to the genus Cucumis L. [41].

This study aims to identify and characterize repetitive sequences in Passiflora edulis genome, using Next-Generation Sequencing (NGS) data and bioinformatics analysis by RepeatExplorer [42], and finally produce repetitive DNA probes for chromosome mapping through FISH. Our work focused on the analysis of TEs and SatDNAs associated to centromeres, considering that they are species-specific markers widely used for the identification of chromosomal alterations, an important tool for genetic improvement programs and evolutionary studies of passion fruit.

\section{Results}

\section{Graph-based identification of repetitive DNA,} classification and chromosomal mapping of satellite DNA Among the total of 11,493,782 paired-end reads obtained by sequencing using Illumina MiSeq ${ }^{\circ}$ platform, 2,368,626 reads were analyzed by RepeatExplorer [42, 43]. The paired-end reads were clustered based on similarities and analyzed using graphical representation. The RepeatExplorer grouped 2,059,943 reads as repetitive DNA (87\%), and 308,692 as unique, non-grouped sequences (13\%) (Fig. 1). Clustering based on reads similarity generated 65,578 CLs. However, 223 CLs have been identified as the most representative (more than $0.01 \%$ of reads), containing repetitive elements that are more abundant in the genome. Automatic sorting of the CLs, based on reads homology with databases, enabled the observation of higher proportions of LTR retrotransposons in the genome, totaling $53 \%$ of $P$. edulis genome. Ty3/Gypsy superfamily was the most abundant (33.33\%), followed by Ty1/ Copy (16.89\%) (Fig. 2). The reads with homology for rDNA (5S and 45S) had around 1\% genome proportion, and the lowest proportion observed was for SatDNAs, reaching less than $0.1 \%$ (Fig. 2).

The analysis for repetitive elements identification prioritized the elements possibly associated with the centromeric region. The parameters were based on the graphic layout (circular or star-shaped) and homology classification of reads (hits) with the RepeatMasker databases and the customized library (satDNAs and TEs associated with centromere). In the automatic classification, among the 223 CLs, only one was significantly classified as satellite, CL 207 presented the expected patterns for Satellite DNA:

\section{$\square$ clustered sequences for DNA repetitive analysis}

$\square$ single non-clustered sequences

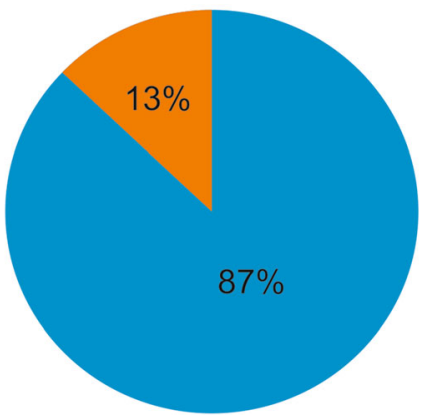

Fig. 1 Proportion of total 2,368,626 reads in the genome of Passiflora edulis by RepeatExplorer. $87 \%$ of the reads were grouped for repetitive DNA classification (blue) and 13\% of reads as single copies (orange)

graphic showing a circular layout (Fig. 3a), reads homology in the RepeatMasker databank with relevant similarity to satellite ( $42.45 \%$ hits), and $28.85 \%$ similarity (hits) to centromeric DNA of Arabidopsis thaliana L. from the customized library. CL 207 was composed by only four contigs, which were submitted to BLAST (Basic Local Alignment Search Toll) in the GenBank/NCBI, showing high similarity with the $5 \mathrm{~S}$ ribosomal gene described for Beta vulgaris L. and Allium tuberosum Rottler ex Spreng (both with 97\% identity, for contigs 1 and 3). The other two contigs (2 and 4) showed no similarities in the GenBank. The initial goal was to locate only the SatDNAs associated with the centromere, for which reason contig 2 (PeSat_1) was selected for analysis and chromosome mapping for presenting greater representation in the genome (depth of reads $x$ size) in comparison to contig 4 (Fig. 3b). The results of FISH revealed two evident hybridization sites at the terminal region of the fifth homologous pair (Fig. 4). The markings were reproducible and unambiguous for all analyzed mitotic metaphases analyzed.

\section{Satellite DNA identification by tandem repeat analyzer (TAREAN) and chromosome mapping}

Two CLs were identified as Satellite DNAs by TAREAN, named PeSat_3 (CL 118) and PeSat_2 (CL 69), with respective sizes of 145 and $342 \mathrm{pb}$, and both exhibited graphics with a circular layout. PeSat_3 presented $C$ and $P$ indexes with values equal to 1.0 and for PeSat_2, the value of $C$ was equal to 0.79 and $P$ was equal to 0.97 (Table 1). The reads connected in the graph were decomposed into K-mers, 5-mers for CL 118 and 13-mers for CL 69, which refer to all possible substrings (of length $\mathrm{k}$ ) from the reads of DNA sequencing. The number of $k$-mers and coverage $k$-mer (expected number times of each k-mer is seen) are shown in Table 1. The 


\begin{tabular}{|c|c|c|c|c|c|c|c|c|}
\hline$\square$ unknown & $\square$ ltr/gypsy & $\square$ Itr/copia & \multicolumn{2}{|c|}{$\square$ organellar DNA } & $\square$ Itr/unsp & fied & $\square \mathrm{rDNA}$ & $\square$ satellite \\
\hline 50.000 & 40.800 & & & & & & & \\
\hline 40.000 & & 33.330 & & & & & & \\
\hline 30.000 & & & & & & & & \\
\hline 20.000 & & & 16.895 & & & & & \\
\hline 10.000 & & & & 4.830 & 2.850 & 1051 & & \\
\hline 0.000 & & & geno & e proport & n \% & & & \\
\hline
\end{tabular}

analysis of k-mers was used for the reconstruction of the monomer and consensus represented by the DeBruijn graph (Fig. 5). Based on the DeBruijn graph, it is possible to select the most preserved sequence for the synthesis of oligonucleotides. However, in the present work, the consensus monomers were used to design sense and anti-sense primers by Primer3 plus program version 4.0. (Fig. 5 and Table 2). The search for local similarities between sequences performed on GenBank/NCBI for both CLs did not identify significant similarities with sequences available in the database. Automatic sorting found no similarities to a potential LTR element or rDNA.

Chromosome mapping of the PeSat_2 and PeSat_3 satellites revealed distinct hybridization sites, with reproducible and unambiguous markings for all analyzed mitotic metaphases (Figs. 6 and 7). For PeSat_3 the hybridization sites were observed in subterminal regions of the chromosomes, with markings on the short arms and long arms in three pairs of chromosomes (1, 3 and 8), and markings in just the short arms of six chromosome pairs (2, 4, 5, 6, 7 and 9)
(Fig. 6a'). Chromosome mapping of PeSat_2 revealed four hybridization sites, with strong signals on terminal regions of the short arms of chromosomes 7 and 9 (Fig. 7).

\section{Classification and chromosomal mapping of LTR retrotransposons}

The CLs were analyzed regarding their similarity with preserved protein domains RT, INT and GAG of the LTR retrotransposons. Nine CLs were identified with the RT domain, six with the INT domain and eight with the GAG domain. After multiple alignments for the evaluation of similarity between the CLs (data not shown), seven divergent CLs were selected for probes and chromosomal mapping. The selected CLs were 6, 11 and 94 (RT domain), with respective sizes of 1086, 411 and 2274 pb (Table 2); CLs 36, 86 and 135 (INT domain), with respective sizes 924, 1122 and $946 \mathrm{pb}$ (Table 2); and CL 43 (GAG domain), with size of $484 \mathrm{pb}$ (Table 2). Each CL was classified as the superfamily and family for the element. Graphs were built from the grouping of similar reads, where in the domains identified in the CL

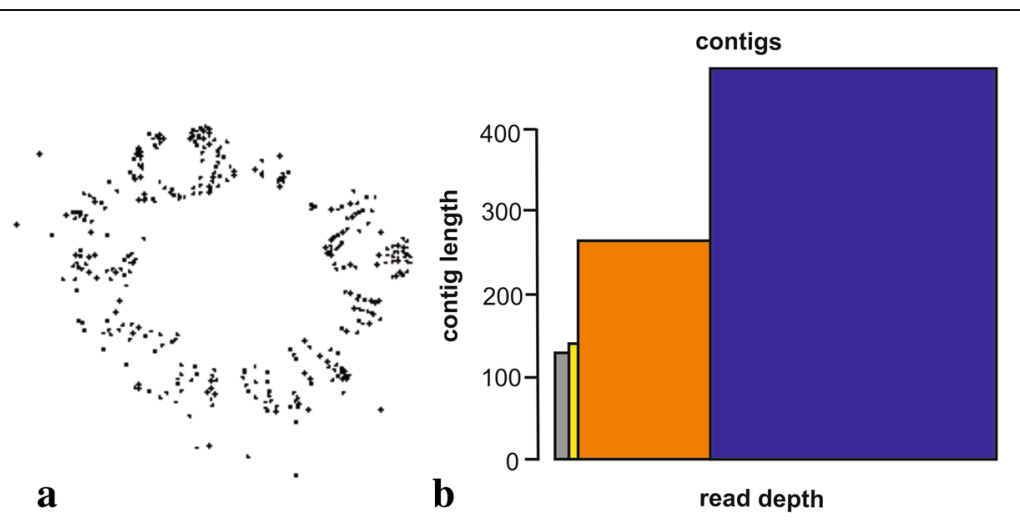

Fig. 3 Graphic analysis of CL 207 in Passiflora edulis. Graphic layout detected on graph-based clustering analysis (a); Contigs distribution according to size and depth of the reads. Contig 1 (blue), contig 2 (grey), contig 3 (orange) and contig 4 (yellow) (b) 


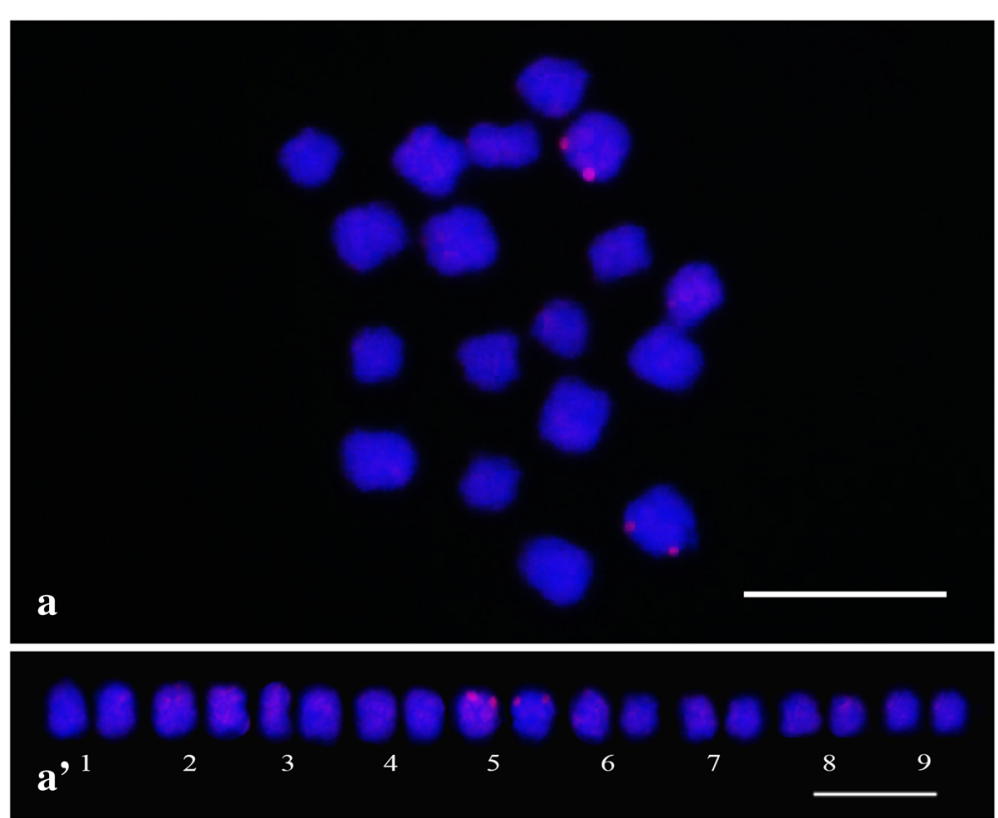

Fig. 4 FISH in Passiflora edulis $(2 n=18)$. Hybridization sites for CL 207 (PeSat_1) (a); karyogram showing signals on terminal regions of the short arms of the fifth homologous pair $\left(a^{\prime}\right)(B a r=10 \mu m)$

were represented by different colors. In addition, column graphs show the total numbers of hits similarity for each family, associating the protein domain and the classified element (Figs. 8, 9 and 10).

The preserved RT domain enabled the classification of CLs 6 and 11 as Ty3/Gypsy/Chromovirus (Fig. 8a, b) and CL 94 as Ty1/Copy/Maximus-SIRE (Fig. 8c). For the INT domain, CLs 36 and 135 were classified as Ty3/ Gypsy/Athila (Fig. 9a, c) and CL 86 as Ty1/Copy/Maximus-SIRE (Fig. 9b). Finally, for the GAG domain, CL 43 was classified as Ty1/Copy/Angela (Fig. 10).

The chromosome mapping for all CLs of protein domains showed distinct and reproducible markings on the analyzed mitotic metaphases, with scattered patterns in most chromosomes. The distribution pattern was similar among most retrotransposons. CL 6 hybridized mainly in the pericentromeric regions, showing signals in the interstitial regions, which diminish or disappear in centromeric and telomeric regions (Figs. 11 and 12a). CLs 11, 36, 94, 86 and 135 presented strong hybridization signals, with specific and dispersed sites in most chromosomes (Figs. 11 and 12b, c, d, f). CLs 86 and 135 were the only ones without hybridization sites in some of the chromosome pairs. More specifically, CL 86 did not present hybridization sites in the last chromosome pair and CL 135, in the fourth and seventh chromosome pairs (Figs. 11 and 12d, f). CL 43 presented the greatest abundance and distribution of hybridization sites in all chromosomes, with very strong signals (Figs. 11 and 12g).

\section{Discussion}

The in silico genomics analysis made it possible to characterize repetitive DNA sequences in $P$. edulis, as well to determine their in situ location in the karyotype

Table 1 Results of the TAREAN analysis identifying Clusters (CLs) of Satellite DNA in Passiflora edulis

\begin{tabular}{lllllll}
\hline $\begin{array}{l}\text { Cluster/Satellite } \\
\text { name }\end{array}$ & $\begin{array}{l}\text { Genome } \\
\text { proportion (\%) }\end{array}$ & $\begin{array}{l}\text { Consensus } \\
\text { length }(\mathrm{pb})\end{array}$ & $\begin{array}{l}\text { K-mer } \\
\text { number }\end{array}$ & $\begin{array}{l}\text { K-mer } \\
\text { coverage }\end{array}$ & $\begin{array}{l}\text { Connected } \\
\text { component } \\
\text { index }(C)\end{array}$ & $\begin{array}{l}\text { Pair completeness } \\
\text { index }(P)\end{array}$ \\
\hline CL118/PeSat_3 & 0.064 & 145 & 5 & 0.92 & 1.0 & 1.0 \\
CL69/PeSat_2 & 0.16 & 342 & 13 & 0.76 & 0.79 & 0.97 \\
\hline
\end{tabular}



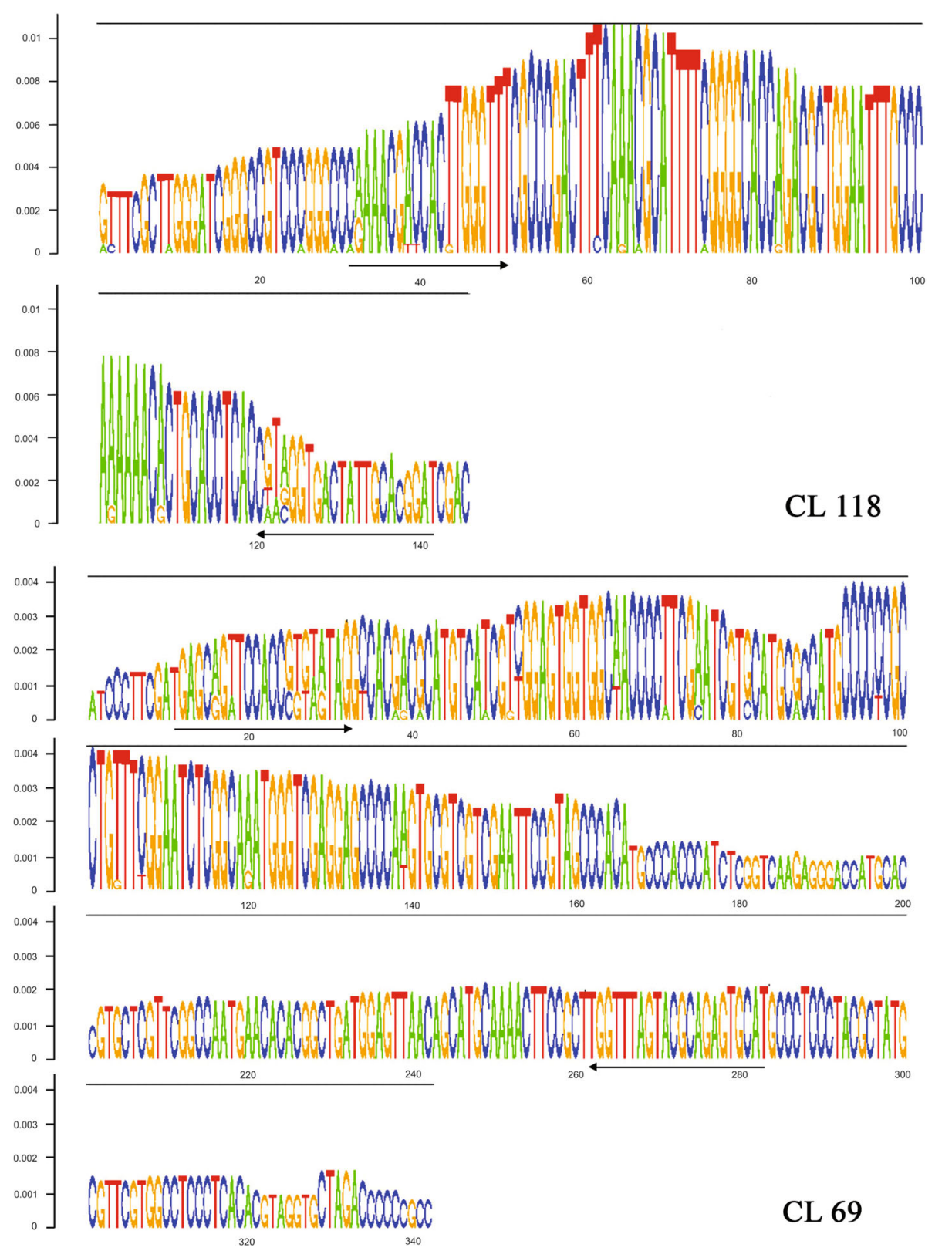

Fig. 5 DeBruijn graphs for the consensus sequences of Satellite DNA in Passiflora edulis, built from the highest frequency of 5-mers (CL 118-145 pb, PeSat_3) and 13-mer (CL-69 - 342 pb, PeSat_2). The arrows indicate the sense and anti-sense primer sequences used for probe synthesis

by FISH. The RepeatExplorer pipeline, used for in silico analysis, has been widely used in the study of repetitive DNA in plants, and publications are increasing. The RepeatExplorer has many advantages because it does not require a reference genome for contigs assembling, offering an easy-to-use interface, free webserver, pre-processing of the sequencing data, fast analysis and with detailed and robust results.

In P. edulis, the low-coverage sequencing (2.2x) was enough to provide a good representation of the repetitive sequences. A very similar proportion was obtained for Coccicinea grandis, with $2.7 x$ genomic coverage, providing satisfactory results in the analysis of TEs by RepeatExplorer [44]. Other works have shown the efficiency of low-coverage sequencing in studies with repetitive DNA [42, 45-48].

The graph-based clustering of reads has identified a high proportion of repetitive DNA in the genome of $P$. edulis, around 59\% (Fig. 2). The high value of repetitive DNA is commonly found in plant genomes [8]. Among the classified types of repetitive DNA, there was a higher prevalence of LTR retrotransposons, amounting to 53\% 
Table 2 Characterization of Satellite DNAs and LTR retrotransposons identified in the genome of Passiflora edulis

\begin{tabular}{|c|c|c|c|c|c|c|c|}
\hline Type analyse & Cluster ID & $\begin{array}{l}\text { Reads Size } \\
(\mathrm{pb})\end{array}$ & $\begin{array}{l}\text { Genome } \\
\text { Proportion } \\
\text { (\%) }\end{array}$ & GC (\%) & $\begin{array}{l}\text { Classification/ } \\
\text { Localization }\end{array}$ & Primers $\left(5^{\prime}-3^{\prime}\right)$ & $\begin{array}{l}\text { Number acession } \\
\text { GenBank }\end{array}$ \\
\hline Based graphics & $\begin{array}{l}\text { CL } 207 \\
\text { PeSat_1 }\end{array}$ & 128 & 0.01 & 49 & $\begin{array}{l}\text { Satellite } \\
\text { Colocalised region } 5 S \text { rDNA }\end{array}$ & $\begin{array}{l}\text { L-ATGCCTCACCCACTGTCTIT } \\
\text { R-TGTTIAAGGCGTTTCCTTGC }\end{array}$ & MF 401643 \\
\hline \multirow[t]{2}{*}{ TAREAN } & $\begin{array}{l}\text { CL } 69 \\
\text { PeSat_2 }\end{array}$ & 342 & 0.16 & 59 & $\begin{array}{l}\text { Satellite } \\
\text { Colocalised region } 45 \mathrm{~S} \text { rDNA }\end{array}$ & $\begin{array}{l}\text { L-TGAGCAGTTCCACCGTGTATAG } \\
\text { R-ATGCACTCTGCGTACTAAACCA }\end{array}$ & MF 401645 \\
\hline & $\begin{array}{l}\text { CL } 118 \\
\text { PeSat_3 }\end{array}$ & 145 & 0.06 & 57 & $\begin{array}{l}\text { Satellite } \\
\text { Subterminal }\end{array}$ & $\begin{array}{l}\text { L-CAAAACGACCACTTGGGTTT } \\
\text { R-ATCCGTGCAATAGTCACCTACG }\end{array}$ & MF 401644 \\
\hline \multirow{7}{*}{$\begin{array}{l}\text { Protein } \\
\text { domains } \\
\text { tools }\end{array}$} & $C L 6$ & 1086 & 1.32 & 47 & $\begin{array}{l}\text { Ty } 3 / \text { Gypsy/Chromovirus } \\
\text { Pericentromeric regions }\end{array}$ & $\begin{array}{l}\text { L-GGAGCTCCAGTTITGTTCGT } \\
\text { R-TGTCTGCAAAACAGTCCTCAA }\end{array}$ & MF 401635 \\
\hline & CL 11 & 411 & 1.10 & 47 & $\begin{array}{l}\text { Ty3/Gypsy/Chromovirus } \\
\text { Disperse all chromosome }\end{array}$ & $\begin{array}{l}\text { L-ACTGCCGCTCTCTCAGAATC } \\
\text { R-TGGCACATTCCGGTTATGTAT }\end{array}$ & MF 401636 \\
\hline & $C L 36$ & 924 & 0.78 & 48 & $\begin{array}{l}\text { Ty3/Gypsy/Athila } \\
\text { Disperse all chromosome }\end{array}$ & $\begin{array}{l}\text { L-CAGTATGCCTTGTGTTCGAG } \\
\text { R-TGCATATGAGTTTGTCCTACG }\end{array}$ & MF 401639 \\
\hline & CL 43 & 484 & 0.67 & 45 & $\begin{array}{l}\text { Ty1/Copia/Angela } \\
\text { Disperse all chromosome }\end{array}$ & $\begin{array}{l}\text { L-TTCGGCTGAGTTTCAGAAG } \\
\text { R-GTGCAGCTCAGTAGGGGATA }\end{array}$ & MF 401642 \\
\hline & $C L 86$ & 1123 & 0.32 & 33 & $\begin{array}{l}\text { Ty1/Copia/Maximus-Sire } \\
\text { Disperse most chromosome }\end{array}$ & $\begin{array}{l}\text { L-AGCTGTGTTAACGGCTTCAG } \\
\text { R-ACTTGGGCATGCTAGTTTTG }\end{array}$ & MF 401640 \\
\hline & CL 94 & 2274 & 0.28 & 35 & $\begin{array}{l}\text { Ty1/Copia/Maximus-Sire } \\
\text { Disperse all chromosome }\end{array}$ & $\begin{array}{l}\text { L-CTTGTTGAACGGCCTAAGGA } \\
\text { R-ATTTGGCATCCTCCATCTTG }\end{array}$ & MF 401637 \\
\hline & CL 135 & 946 & 0.11 & 46 & $\begin{array}{l}\text { Ty3/Gypsy/Athila } \\
\text { Disperse most chromosome }\end{array}$ & $\begin{array}{l}\text { L-GCACTTCTCCCAGTTCAGGA } \\
\text { R-GGCGGTATGACAGTGGTTCT }\end{array}$ & MF 401638 \\
\hline
\end{tabular}

(Fig. 2). TEs (DNA transposons or retrotransposons) generate substantial variation in genome size in several species when performing their own drive mechanisms, such as observed in maize, in which TEs represent $90 \%$ of the genome [49]. LTR retrotransposons are the most abundant elements in the genome of plants, possibly because they perform their transposition mediated by mRNA through a replication mechanism, known as "copy and paste", thus increasing the size of the genome $[18,20]$. The long repetitive sequences present at the endings of the retrotransposons do not encode polypeptide but play an important role in the regulation of retroelements [21].

The LTRs classification revealed a frequency twice as high for superfamily Ty3/Gypsy (33.33\%) in the genome when compared to Ty1/Copy (16.89\%) (Fig. 2). The genomes for Pisum sativum L., Glycine max, Silene latifolia Poir., Feestuca pratensis Huds., Solanum lycopersicum and three Helianthus species have also shown higher prevalence of Ty3/Gypsy over Ty1/Copy [43, 47, 50-52]. However, in the Eleocharis genome was found greater predominance of Ty1/Copy compared to Ty3/Gypsy [53]. The main difference between superfamilies Ty3/Gypsy and Ty1/Copy is in the structural organization of their intermediate polyprotein molecule, and both are the most frequent and diversified forms in the genomes of eukaryotes [16, 21].

Contrary to the abundance of retroelements, studies have reported low frequency of Satellite DNAs in plant genomes. In the present study, only two among the 223
CLs obtained were classified as satellites, representing less than $0.1 \%$ of the genome (Fig. 2). Corroborating this result, genomic analyses of Passiflora through the BAC-end library sequencing also showed a very low number of SatDNAs; only one was characterized as satellite among 4774 repetitive elements founded [31]. Similarly, after examination of Coccinia grandis L. Voigt by RepeatExplorer, only two of the 21 repetitive elements were satellites [44]. In turn, $3 \%$ of the genome was classified as satellite in Glycine $\max$ L., which is considered high for this species [43]. The low proportion of SatDNAs, commonly found in in silico analyses, may be related to the high variability among and between species, which makes it difficult the identification of sequences with homology [44].

Satellite DNAs are composed by highly repetitive sequences in tandem, and are generally located in heterochromatin regions (found mainly in centromeric or subtelomeric regions) $[8,21]$. The SatDNA hybridization of PeSat_1 (CL 207) was expected in the centromeric region, due to its characterization as SatDNA, circular graph and hits with similarities to centromere DNA in other species. However, the presented profile was not centromeric, with hybridization sites restricted to a pair of homologous chromosomes co-located with the $5 \mathrm{~S}$ rDNA sites (Fig. 4). As rDNA presents many copies in tandem, it justifies the circular layout of the graph. Because two contigs of CL 207 (not used for the synthesis of the probe) showed homology to $5 \mathrm{~S}$ ribosomal gene through GenBank, this hybridization result can be 

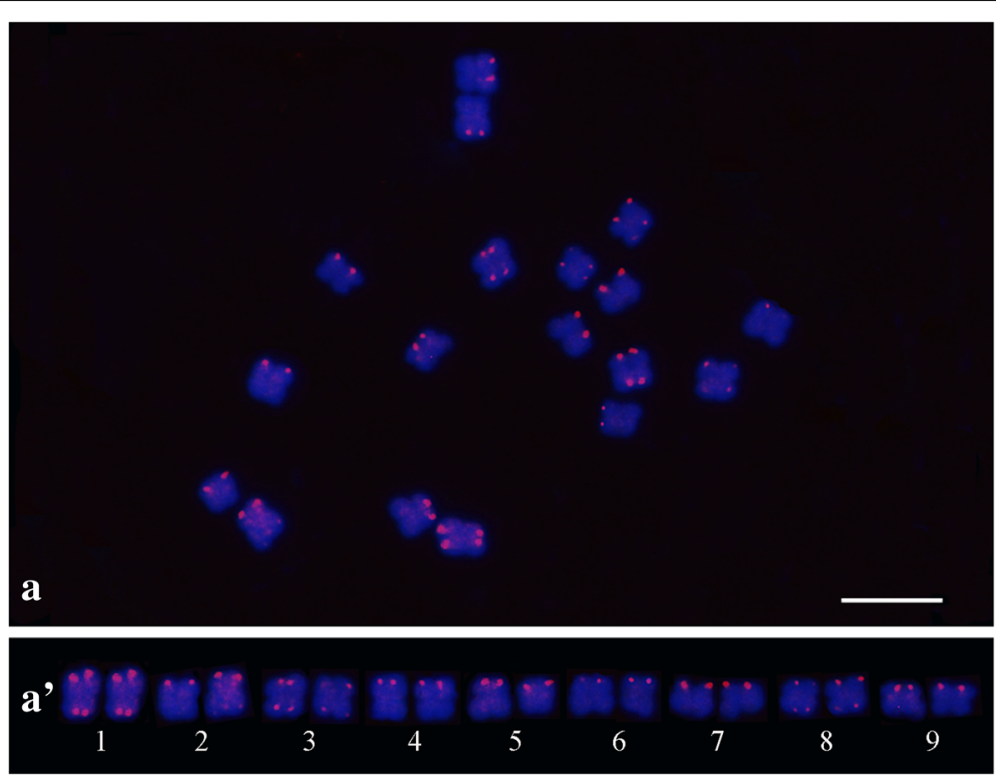

Fig. 6 Chromosome mapping by FISH in Passiflora edulis $(2 n=18)$. Hybridization sites of PeSat_3 (CL 118) (a); karyogram showing three chromosomal pairs with hybridization sites in short and long arms (1, 3 and 8$)$ and in just the short arms of six chromosome pairs (2, 4, 5, 6, 7 and 9) (a') (Bar=10 $\mu \mathrm{m})$

justified by the proximity of the reads grouped in the same CL, even when homology has not been verified in the databases for that contig. In addition, the $5 \mathrm{~S}$ rDNA consists of repetitions units containing a transcription region with approximately $120 \mathrm{pb}$, and non-transcribed spacer (NTS) with highly variable size (100-700 pb). Because the coding region is highly preserved and the NTS region varies widely between species, the variance between genus can be due to divergence of the NTS sequence [54]. Thus, it is presumed that the sequence determined by CL $207(128 \mathrm{pb})$ is a satellite associated with the NTS region. The polymorphisms of the NTS regions (size variation and chromosome distribution) can be used to compare species from different clades and suggest evolutionary
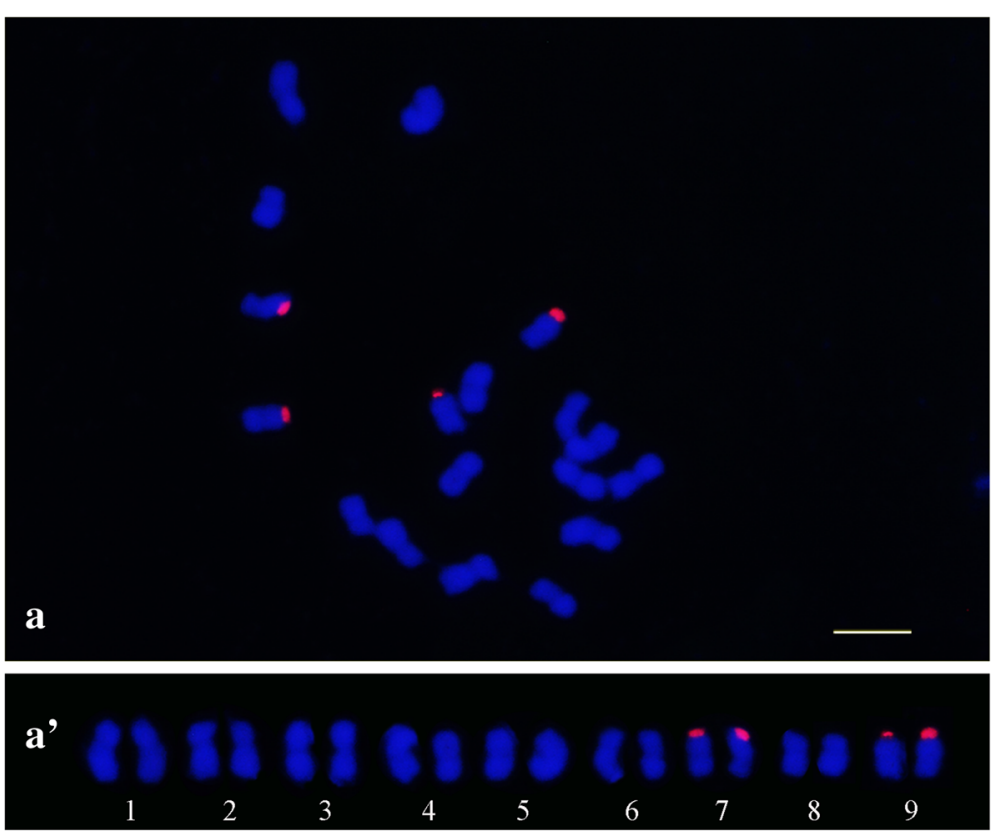

Fig. 7 FISH in metaphasic chromosomes of Passiflora edulis $(2 n=18)$. Hybridization sites of PeSat_2 (CL 69) (a); karyogram showing signals on terminal regions of the short arms of chromosomes 7 and $9\left(a^{\prime}\right)(B a r=10 \mu m)$ 

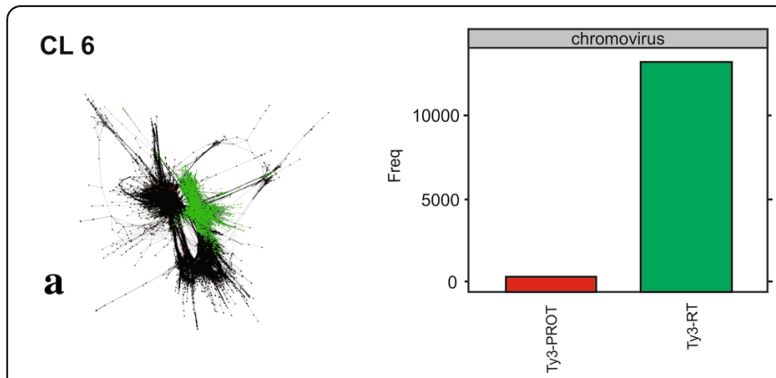

CL 11
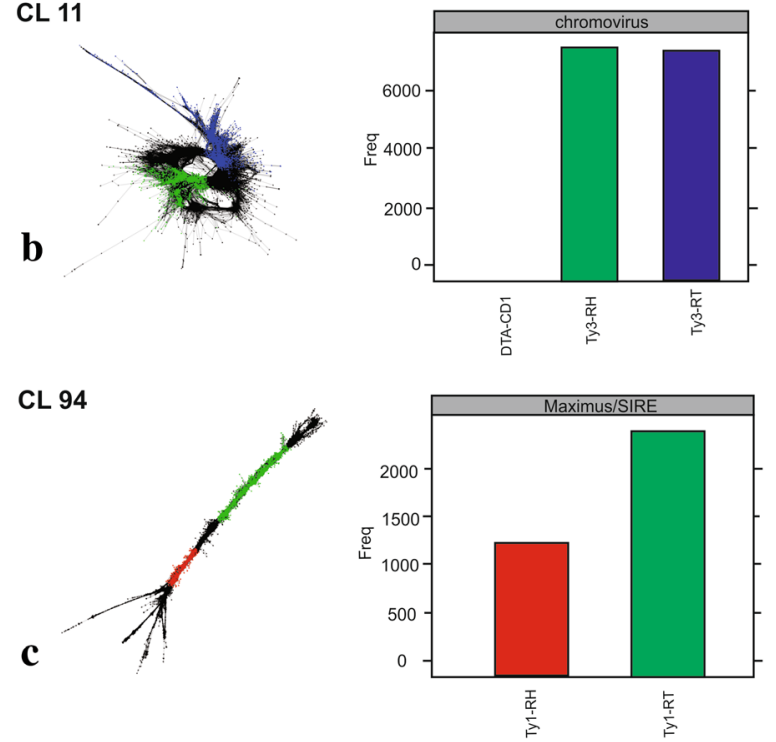

Fig. 8 Graphic layouts for CLs 6, 11 and 94 detected by reads clustering with similarities and classified through the RT protein domain in Passiflora edulis. CLs 6 (green) and 11 (blue) were classified as Ty3/Gypsy/Chromovirus (a, b); CL 94 (green) was classified as Ty1/Copy/Maximus-SIRE (c)

mechanisms. 5S rDNA non-transcribed spacers (5S-NTS) sequences have being used as phylogenetic markers in plant species, as cotton [55], wheat [56], goosefoot [57], and orchid [58], among others.

In the present study was not possible to identify the centromere DNA for $P$. edulis, indicating a highly species-specific, low-preserved centromeric DNA, considering that it was not observed significant homology with other plant species for precise classification. Centromeres can also present a large number of retrotransposons or a single-copy DNA, thus interfering in the detection of in tandem repeats [22, 59, 60]. Centromeres formed mainly of single-copy DNA has been observed in five potato centromeres, and no satellite repetition has been identified [61]. Ten distinct families of centromeric retrotransposons were grouped in the genus Coffea [60] and Sugarcane centromeres contain both satellite and retrotransposon DNAs [62].

The tools used in this work did not enable the identification of isolated centromere DNA sequences. Therefore,

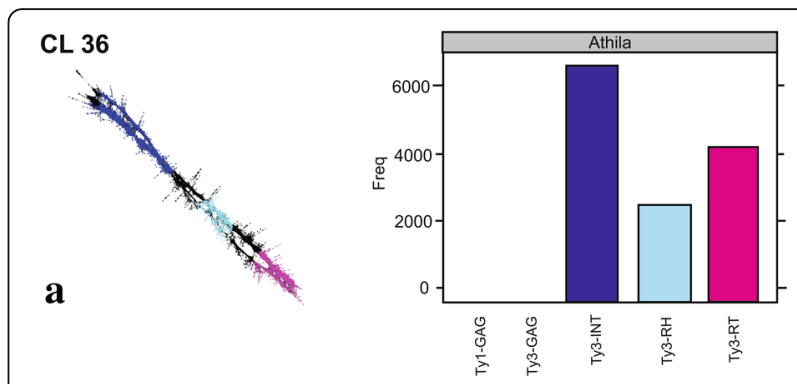

CL 86
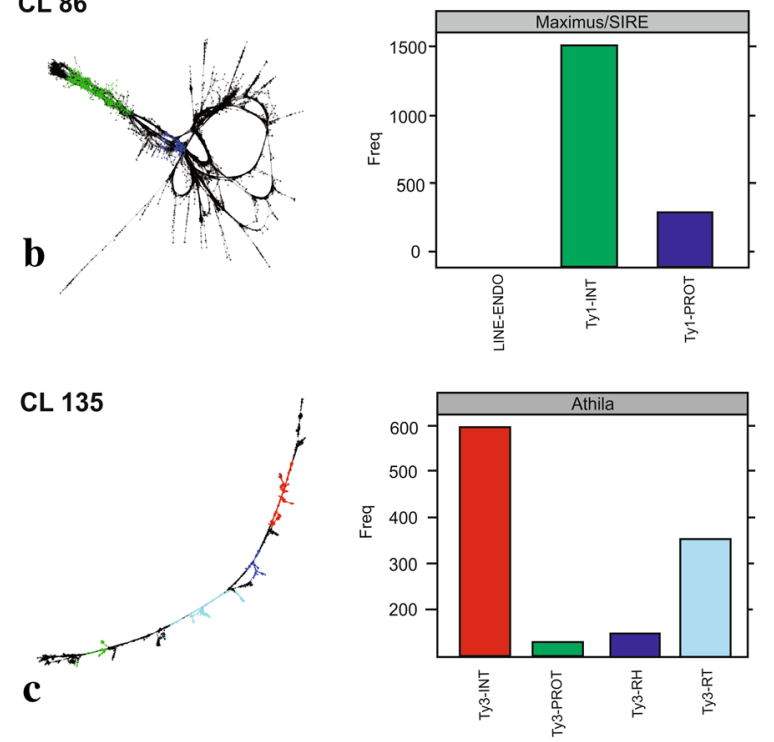

Fig. 9 Graphic layouts for CLs 36, 86 and 135 detected by reads clustering with similarities and classified through the INT protein domain in Passiflora edulis. CLs 36 (blue) and 135 (red) were classified as Ty3/Gypsy/Athila (a, c); CL 86 (green) was classified as Ty1/Copy/Maximus-SIRE (b)

other strategies can be employed for $P$. edulis based on the isolation of DNA in this region, as performed by Chromatin immunoprecipitation (Chip), which uses an antibody against a specific protein in the centromere/ kinetochore complex for immunoprecipitation, so that the linked DNA co-precipitates and can then be sequenced (Chip-seq) [25, 62, 63].

TAREAN is a tool that uses k-mers frequency, which is more suitable for the reconstruction of monomers from a non-assembled short-sequence reads, and therefore can complete the gaps unfilled by graph-based clustering [46]. In $P$. edulis, TAREAN enabled the detection of two new satellites repeats, undetected on the previous analysis. PeSat_3 (CL 118) was characterized as high-confidence satellite for presenting $C$ and $P$ indexes equal to one, and PeSat_2 (CL 69) was characterized as low-confidence satellite $(C=0.79, P=0.97)$, respecting the recommended values of $C>0.7$ and $P>$ 0.4 for this classification (Table 1). Vicia faba L. was the species with the highest number of satellites 

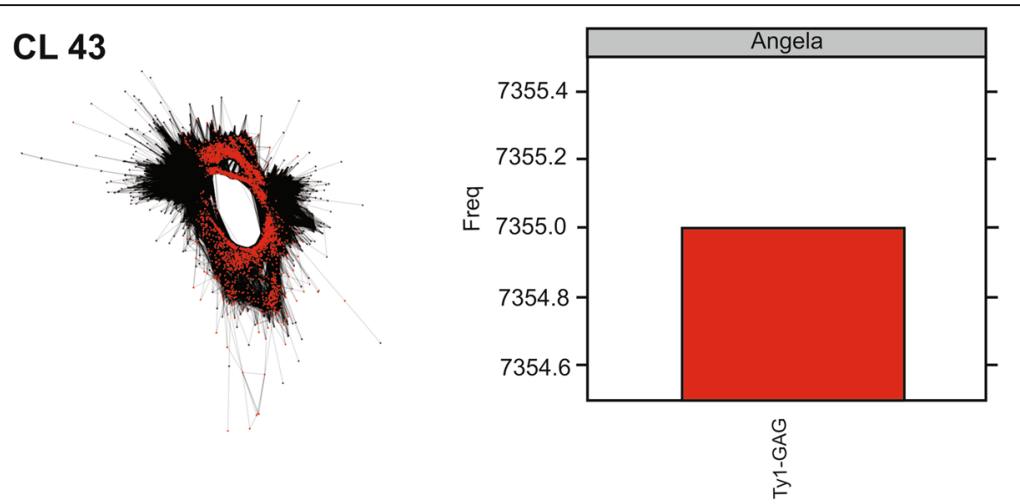

Fig. 10 Graphic layout for CL 43 detected by reads clustering with similarities and classified through the GAG protein domain (red) in Passiflora edulis, as Ty1/Copy/Angela
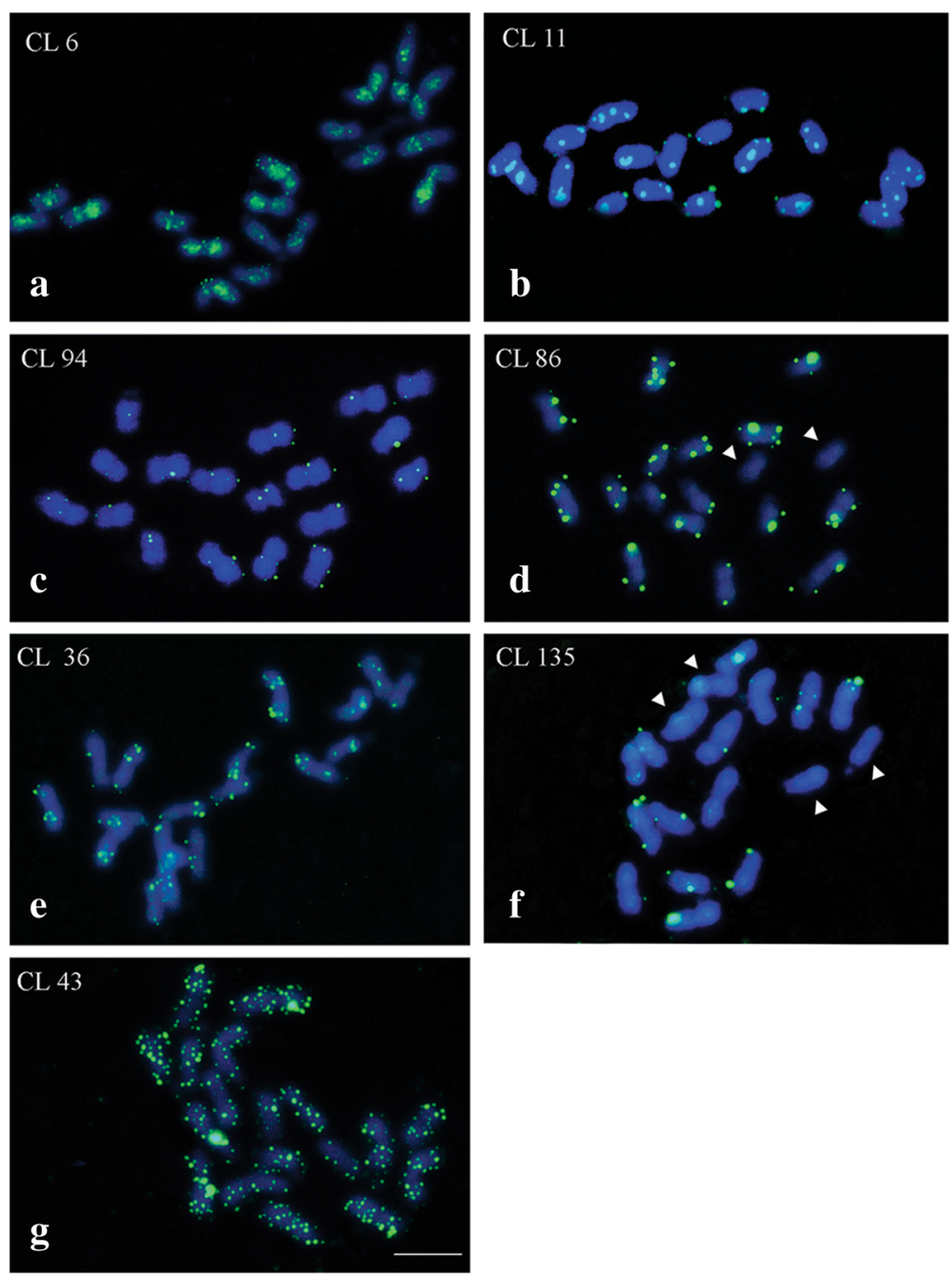

Fig. 11 Chromosome mapping of LTR retrotransposons clusters in Passiflora edulis ( $2 n=18)$. Hybridization profiles observed in: CLs 6 and 11 classified as element Ty3/Gypsy/Chromovirus (a, b); CLs 86 and 94 as element Ty1/Copy/Maximus-SIRE (c, d); CLs 36 and 135 as element Ty3/ Gypsy/Athila (e, f); CL 43 as element Ty1/Copy/Angela $(\mathbf{g})(B a r=10 \mu \mathrm{m})$ 

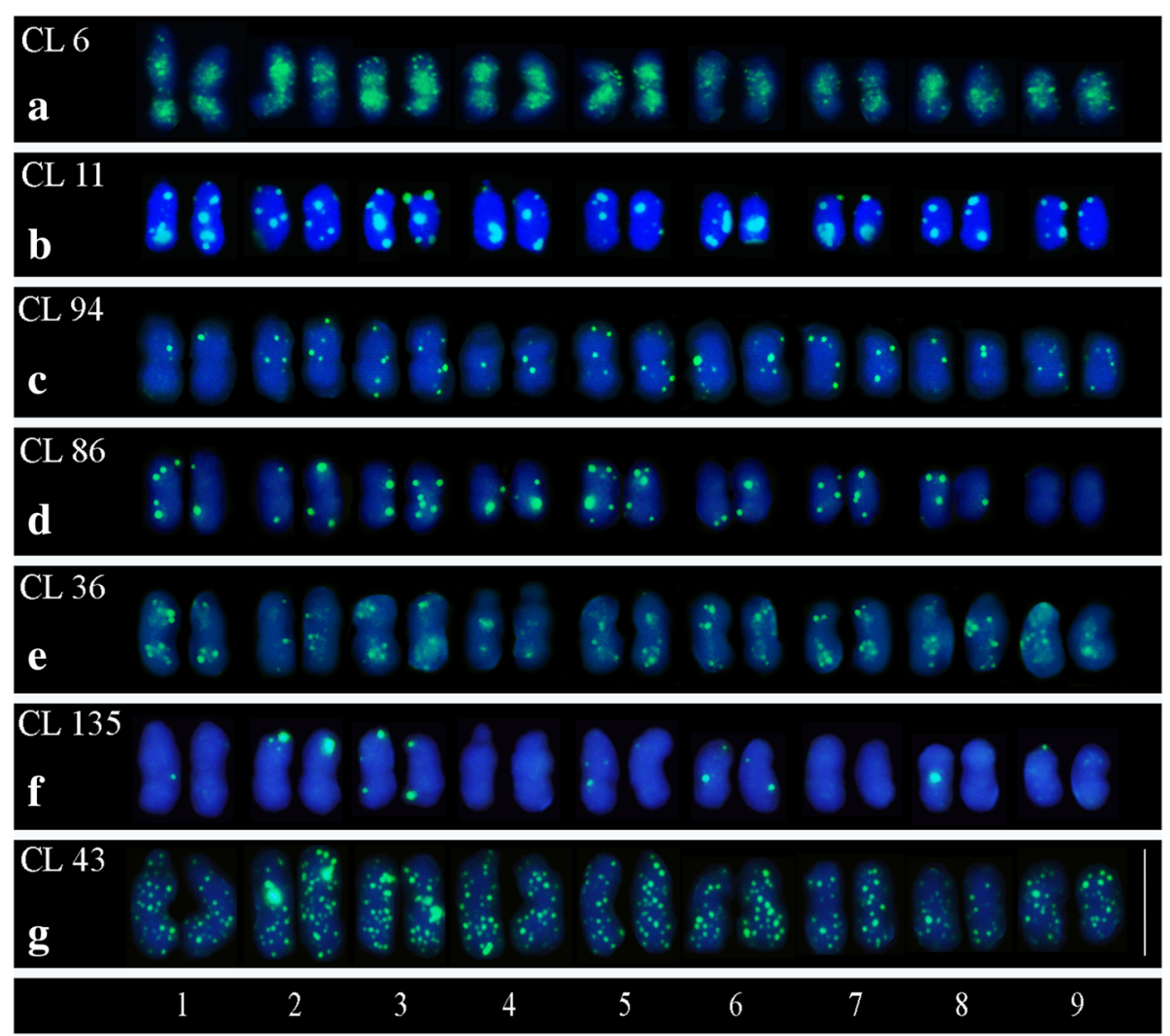

Fig. 12 Karyogram for LTR retrotransposons clusters in Passiflora edulis $(2 n=18)$. CLs 6 and 11 (Ty3/Gypsy/Chromovirus) (a, b); CLs 86 and 94 (Ty1/Copy/Maximus-SIRE) (c, d); CLs 36 and 135 (Ty3/Gypsy/Athila) (e, f); CL 43 (Ty1/Copy/Angela) (g) (Bar = 10 um)

registered using TAREAN, with 11 new identified satellites [46].

The chromosomal hybridization observed for PeSat_3 $(145 \mathrm{pb})$ has shown signals at the subtelomeric location (Fig. 6). Similar result was observed in S. latifolia, in which a $159 \mathrm{pb}$ satellite was mapped in the subtelomeric region of all chromosomes, and in both arms of most chromosomes [47]. Subtelomeric satellites have been identified in many other plant species, such as potatoes [64], rice [65] and maize [66]. In P. edulis, a very specific pattern was observed for this satellite, present in both arms of three chromosomes and only in the short arms of six chromosomes (Fig. 6). SatDNA sequences are generally species/genus-specific [8], and can help in comparative studies to a better understanding of the evolutionary history of Passiflora.

The results achieved by FISH for PeSat_2 show its co-located with 45S rDNA sites (Fig. 7), presenting four hybridization sites in the same locus for the $26 \mathrm{~S}$ rDNA probe (data not shown). The $342 \mathrm{pb}$ size of the consensus monomer may indicate that these sequences are derived from the IGS region (large intergenic spacers). In eukaryotes, the general standard of organization of rDNA genes is similar, wherein each unit is formed by rDNA genes (18S, $5.8 \mathrm{~S}$ and 26S), which are separated from one another by small internal transcribed spacers (ITS), and the gene units are separated by large intergenic spacers (IGS), composed by small repetitive sequences (100 $300 \mathrm{pb})$, that are not transcribed but functional in the regulation of genes [67]. In S. latifolia, after analysis of the graph and reconstruction of the sequences, a SatDNA with $313 \mathrm{pb}$ was identified, derived from the IGS region of the $45 \mathrm{~S}$ rDNA [47]. The nearly circular format of the graph for PeSat_2 (Table 1) reflects the in tandem organization of the multiple copies of the rDNA repeat unit, and were therefore detected as low-confidence satellites by Tarean. In $V$. faba, a consensus monomer with $168 \mathrm{pb}$, characterized by TAREAN as low-confidence repetition satellites, also presented satellites derived from the IGS region of the $45 \mathrm{~S}$ rDNA [46]. The spacer sequences do not contribute to the rRNA synthesis, are under low selective pressure, and are susceptible to high rates of mutation, and therefore are not preserved between species but within species. These features allow the use of spacer regions as a molecular tool for classification at species level and can recognize recent changes in evolutionary history [67]. 
LTR retrotransposons comprise a group of repetitive DNAs in the genome of plants, with sequence sizes varying between 300 to 5000 nucleotides [21]. The CLs of $P$. edulis, classified as LTRs, have not represented the entire element, and the sizes observed ranged from 411 to 2274 nucleotides (Table 2). The graph layouts obtained in the analyses of protein domains revealed a variation between circular, linear and circular/linear (Figs. 8, 9 and 10). The circular layout is characteristic to either SatDNA or terminal regions repeats, such as LTR retrotransposons. These linear graphs result from a lack of sufficient coverage of the sequencing or from the presence of low-coverage variable sequence regions [43]. The sequences must be sufficiently frequent in the genome to be represented in low-coverage data, must be identified as repetitions and quantified with precision [47].

A directly proportional relationship between abundance of CL in the genome and hybridization signals has been observed, i.e. the higher the proportion in the genome, the greater the number of scattered sites in the chromosomes. CL 6 presented higher proportion in the genome (1.32\%) and CL 135 presented the lowest $(0.11 \%)$ (Table 2). Thus, more hybridization sites have been observed for CL 6 than for CL 135 hybridizations (Figs. 11e and 12). However, in the sequences mapping was observed that the hybridization signals were greater for CL 43 (0.67\%) than for CLs 11 and 36 (1.10and 0.78\%, respectively), which may be related to an underestimation of the proportion in the genome for CL43 (Fig. 12).

The repetitive DNA concerning to TEs can appear scattered in the genome, or restricted to specific locations when in tandem repeats [8]. In P. edulis, the LTRs are either scattered or grouped in the chromosomes. In C. grandis CL 10, classified as Ty1/Copy/Angela presented weakly scattered signals in the chromosomes, and CLs 9 and 37, classified as Ty3/Gypsy/Athila, showed signals grouped in the subterminal or the pericentromeric region [44]. Unlike other CLs with scattered hybridization sites, only the CL 6 (Ty3/Gypsy/Chromovirus) presented preferential association sites in the pericentromeric regions in P. edulis (Figs. 11e and 12a). Comparing the hybridization signals for $C$. grandis and $P$. edulis, the Ty3/Gypsy elements were observed grouped, and the Ty1/Copia elements always showed signals scattered. However, more detailed studies are needed to understand and validate these observations.

The CLs 6 and 11, both classified as Ty3/Gypsy/Chromovirus, showed different patterns of chromosome hybridization sites, wherein CL 11 did not present preferred sites, showing a diversification of this family in the genome (Figs.11e and 12a, b). The chromovirus have a chromodomain with a role in chromatin remodeling and in the regulation of gene expression during the development of eukaryotes [68]. This retroelement can be associated with an important regulatory function of histone-modifier enzymes and the maintenance of pericentromeric heterochromatin, which participates in the control of recombinations involving the centromere [69, 70].

Four TEs families have been identified between the superfamilies Ty1/Copy and Ty3/Gypsy. The families Chromovirus (CLs 6 and 11), Maximus-Sire (CLs 86 and 94) and Athila (CLs 36 and 135) were each represented in two CLs and the Angela family was represented only in CL 43 (Table 2). Recent analysis for Hippophae rhamnoides L. showed that the most families of TEs were represented by one or two clusters, and few were found in multiple clusters, suggesting that when the families are represented in few clusters, they are called conserved families, presenting no changes in the sequence and structure of the element [71]. In turn, families that are present in several clusters indicate high divergence. Thus, we can suggest that $P$. edulis presents a conserved pattern for LTR retrotransposon families.

TEs represent the widest diversity among genomes of phylogenetically similar organisms [20]. TEs are considered sources of new genetic and regulatory information of the genome, and may influence the expression and the dynamics of genetic information, thereby acting directly in the genomes evolution [21]. Studies of diversity, organization and distribution of TEs are important to understanding the role of these elements in the genome.

\section{Conclusions}

New information was generated about the repetitive DNA of the Passiflora edulis genome based on NGS data. The high proportion of repetitive DNA identified by low-coverage sequencing reflects in a higher proportion of LTR retrotransposons of the Ty3/Gypsy superfamily, and these are one of the main responsible elements for the species genome size. The analyses of LTR retrotransposons have contributed to a better understanding of the genomic organization of the TEs in $P$. edulis mostly presenting scattering patterns, and a single pericentromeric marking element, all with plenty of relevant differences in the genome. A few SatDNAs have been observed, with two of them associated to the rDNA regions and one of them to the subtelomeric region, acting as a cytological marker for chromosome organization, considering that those sequences are usually species/genus-specific. Therefore, the information generated in this work provides a starting point for further investigations of Passiflora genome; besides comparisons to related species, which could help the cytogenomic comparison and the the understanding of evolutionary patterns of repetitive sequences and their impact on other scientific areas as toxonomy, phylogeny and breeding. 


\section{Methods}

\section{Plant material and cytological preparation}

Samples of Passiflora edulis $(2 n=18)$ were collected from commercial populations of passion fruit-producing farms in the municipality of Livramento de Nossa Senhora, the state of Bahia (BA), Brazil (latitudes $13^{\circ} 17^{\prime}$ and $15^{\circ} 20^{\prime} \mathrm{S}$ and longitudes $41^{\circ} 05^{\prime}$ and $\left.43^{\circ} 36^{\prime} \mathrm{W}\right)$. The plants were kept at the Germplasm Active Bank (BAG-Passifloras), located at the State University of Santa Cruz (UESC), in the city of Ilhéus, the state of Bahia, Brazil (latitude $14^{\circ} 39^{\prime} \mathrm{S}$, longitude $39^{\circ} 10^{\prime} \mathrm{W}$, altitude $78 \mathrm{~m}$ ). Stakes were arranged in bags with sand, and after 15 days the roots were collected with about one centimeter in length. The root tips were pre-treated in 8-hydroxyquinoline solution (8-HQ) at $0.002 \mathrm{M}$ at room temperature (RT) for $1 \mathrm{~h}$ and an additional $21 \mathrm{~h} \pm 8$ at $10{ }^{\circ} \mathrm{C}$, then washed twice for $5 \mathrm{~min}$ in distilled water, fixed in Carnoy I (ethanol/acetic acid, 3:1, v/v; [72]) for $3 \mathrm{~h}$ at $\mathrm{RT}$, then stored at $-20^{\circ} \mathrm{C}$ for at least $24 \mathrm{~h}$ or until use. The samples were washed twice for $5 \mathrm{~min}$ and incubated in enzymatic solution at $2 \%$ cellulase and pectinase at $20 \%$ for $80 \mathrm{~min}$ at $37^{\circ} \mathrm{C}$. After enzymatic digestion, the rootlets were washed with distilled water and dried with filter paper, then $6 \mu \mathrm{L}$ of $60 \%$ acetic acid was added and they were macerated with the help of a needle and stereoscopic microscope, covered with cover slips, pressed gently with filter paper and frozen in liquid nitrogen for at least $5 \mathrm{~min}$. The coverslips were removed with a scalpel, air-dried and stored at $-20{ }^{\circ} \mathrm{C}$ until the selection of slides with good metaphasic cells to carry out the FISH.

\section{Genomic DNA extraction}

The genomic DNA extraction was performed according to the protocol described by Doyle and Doyle [73], with modifications for Passiflora [74]. The genomic DNA was purified with the addition of $10 \%$ sodium acetate $(3 \mathrm{M}$, $\mathrm{pH} 5.2$ ) and $200 \%$ of the final volume of the anhydrous ethanol at $-20{ }^{\circ} \mathrm{C}$. The quantification of the extracted DNA was performed on Qubit 2.0 fluorometer (Termo Fisher Scientific), using the Qubit dsDNA kit (Q32850). The samples quality was checked by the absorbance ratio $260 / 230$ and $260 / 280$ in Nanodrop equipment (Termo Fisher Scientific).

\section{Next-generation sequencing (NGS)}

The genomic library was built using the Nextera DNA Sample Preparation kit (Illumina ${ }^{\circledR}$ ) with the Nextera index kit (Illumina ${ }^{\oplus}$ ), strictly following the manufacturer's recommendations. Firstly, the fragmentation was performed with $50 \mathrm{ng}$ of the genomic DNA, with purification using the Illustra GFX PCR DNA and the Gel Band Purification kits (GE Healthcare Life Sciences); amplification and linkage of the indexes $\left(72{ }^{\circ} \mathrm{C}\right.$ for $3 \mathrm{~min}$, $98^{\circ} \mathrm{C}$ for $30 \mathrm{~s}, 5$ cycles of $98^{\circ} \mathrm{C}$ for $10 \mathrm{~s}, 63^{\circ} \mathrm{C}$ for $30 \mathrm{~s}$, and $72^{\circ} \mathrm{C}$ for $3 \mathrm{~min}$ ), and purification was performed by magnetic beads (AMPure XP beads GEHelthcare Life Sciences) and washes with $80 \%$ ethanol. The genomic library was quantified with KAPA Library Quantification Kit Illumina ${ }^{\circledR}$ Platforms (KR0405), in ABI Prism real-time PCR equipment (Applied Biosystems), following the manufacturer's protocol for the preparation of the qPCR reactions. The qualitative assessment of the libraries was inferred by the dissociation curve analysis of the graph obtained after qPCR, wherein the presence of adapter dimers was also evaluated. The sequencing was performed at the Laboratory of Molecular Markers at the Center of Biotechnology and Genetics (CBG), UESC, Bahia, Brazil, using the Illumina $\mathrm{MiSeq}^{\oplus}$ platform with the $\mathrm{MiSeq}^{\bullet}$ reagents kit V3 600 cycles (Illumina ${ }^{\oplus}$ ). The methodology strictly followed the "MiSeq ${ }^{\oplus}$ Reagent Preparation Guide (catalog number 15.044.983)", as well as the "MiSeq System User's Guide (part no. 15.027.617_PTB)”.

\section{Bioinformatics using RepeatExplorer}

The identification and characterization of the repetitive DNA families was performed using the RepeatExplorer pipeline [42, 43], implemented in the Galaxy server (http://repeatexplorer.org/), which uses NGS reads for analysis. A total of 11,493,782 paired-end sequence reads (average size of reads $300 \mathrm{pb}$ ) was obtained by sequencing, with $43 \%$ of GC content and genomic coverage of $2.2 \mathrm{x}(1 \mathrm{C}=1.545 .24 \mathrm{Mpb},[75])$. The formula used to calculate the genomic coverage was $\mathrm{Cov}=\left(\begin{array}{lll}\mathrm{N} & \mathrm{x}\end{array}\right) / \mathrm{G}$, wherein $\mathrm{N}$ represents the number of paired-end reads, used in the analysis, $L$ represents the size of reads and $G$ is the size of $1 \mathrm{C}$ content of the species' genome. The adapters were removed with a tool available on the Illumina ${ }^{\oplus}$ platform, and the quality control of the sequencing data were accessed by FastQC (version 0.11.4).

\section{Graph-based identification of repetitive DNA}

Cluster analysis was performed using a graph-based approach to identify clustered read repeats de novo, without the need for a reference genome [41]. Initially, was performed the preprocessing of the reads. The reads were filtered in terms of quality using a cut-off of 30, trimmed and filtered by size $(100 \mathrm{pb})$ to obtain high-quality reads. Interlaced paired reads were sampled randomly to cover $5 \%$ of the genome of the species (772,620 reads). The number of analyzed reads represented $0.15 \mathrm{x}$ of the coverage of the genome (recommended value ranges between $0.01-0.50 \mathrm{x}$ ). Clustering of the reads was accomplished with a minimum overlap of 55 and $90 \%$ similarity. In addition to the characterization of clusters (CLs) using the RepeatMasker database, now available in the program, a custom database was built with consensus repetitive sequences for centromeric 
regions and TEs associated with the centromeric region. This database was constructed from public databases (Repbase, most commonly used database for repetitive DNA, Plant Repeat Database ${ }^{1}$ and NCBI-National Center for Biotechnology Information) totaling 11,868 sequences. At the end of the analysis by RepeatExplorer, the probable CLs containing Satellite DNAs were selected from the automatic classification and the graphic layout. The contigs with highest abundance index in the CL were used for prime design and probe preparations. The sequences were included in the GenBank (Table 2).

\section{Identification of satellite DNA by the tandem repeat analyzer (TAREAN)}

The TAREAN tool available in RepeatExplorer [46] was used for the identification of Satellite DNA. The TAREAN is based on the analysis of reads graphs for the identification of clustered satellites. Later, it used k-mers frequency statistics in the reconstruction of molecular consensus for each satellite CL. The automatic detection of repetition satellites was based on the parameters "Connected component index (C)" and "Pair completeness index $(P)$ ". These are characterized as high-confidence satellites when both assume values close to one. Parameters $C>0.7$ and $P>0.4$ are characterized as low-confidence satellites. The analyses were performed with 250,000 input reads and CL merging option. Both low and high confidence satellites CLs were used for the design of primers and probes for FISH. The identified monomers had their sequences included in the GenBank database (Table 2).

\section{Identification of protein domains of LTR retrotransposons}

The Protein Domain Search tool [42] was used for the identification and analysis of protein domains of LTR retrotransposons, using selected clusters (CLs) analysis as input file. The tool performed analysis of sequences similarity of Passiflora with a database of protein domains for RT, INT and GAG. The output generated for each domain was subjected to filtering with stringency parameters (minimum of $60 \%$ similarity and $40 \%$ identity). The information contained in the reference sequences for protein domains allowed the definition of the superfamily level (Ty1/Copy and Ty3/Gypsy) and the family level (Athila, Angela, Chromovirus, MaximusSIRE, among others). Among the CLs identified in this analysis, the sequences similarities were verified through multiple alignments using MUSCLE on the Phylogeny.fr platform (v 3.8.31) [76, 77]. Among the CLs identified in this analysis, the most divergent CLs were used for chromosomal mapping and their sequences were included in the GenBank (Table 2).

\section{Production of probes for FISH}

The primers for amplification of Satellite DNAs and retroelements protein domains were designed in Primer3Plus [78]. The amplification reactions were prepared on a volume of $50 \mu \mathrm{l}$ containing $10 \mathrm{ng} / \mathrm{ul}$ of gDNA of $P$. edulis, $1 \mathrm{mM}$ dNTPs, PCR buffer 10X, $50 \mathrm{mM} \mathrm{MgCl}_{2}$, $10 \mu \mathrm{M}$ of each primer, $1 \mathrm{U}$ Taq polymerase (Vivantis) and ultrapure water to complete the desired volume. The PCR was performed in thermocycler (Eppendorf Mastercycler,) using the program: $4 \mathrm{~min}$ at $94^{\circ} \mathrm{C}$ for initial denaturation, followed by 30 cycles of $1 \mathrm{~min}$ at $94^{\circ} \mathrm{C}$, $1 \mathrm{~min}$ at $56^{\circ} \mathrm{C}$ and $2 \mathrm{~min}$ at $72^{\circ} \mathrm{C}$. At the end, there was an additional 10 -min extension at $72{ }^{\circ} \mathrm{C}$. In order to verify that the expected fragment amplification occurred, PCR products were subjected to electrophoresis in $1 \%$ agarose gel using DNA molecular weight marker (50pb) (Invitrogen $^{\text {tx }}$ Life Tecnologies). The gel image was captured under ultraviolet light by photo-documentation device L-Pix (Loccus Biotecnologia).

The Satellite DNA probes were marked with digoxigenin-11-dUTP via Nick Translation Mix (Roche, $11,209,256,910)$, with a final concentration of $1 \mu \mathrm{g}$ of the purified PCR product, following the protocol proposed by the manufacturer. The retroelements probes were marked via PCR with biotin-16-dUTP (Roche, $11,093,070,910)$, through a re-PCR of the purified PCR product with the following dNTPs concentration: $1 \mathrm{mM}$ dATP, dCTP and dGTP, $0.65 \mathrm{mM}$ dTTP and $0.35 \mathrm{mM}$ biotin-16-dUTP.

\section{Fluorescent in situ hybridization (FISH)}

The slides treatment for FISH followed the protocol proposed by Schwarzacher and Heslop-Harrison; and Souza et al. $[79,80]$, with modifications made by Melo et al. [81]. Cytological preparations and selected slides with good metaphases were dried in an oven at $37^{\circ} \mathrm{C}$ for $1 \mathrm{~h}$. The slides were treated with $50 \mu \mathrm{g} / \mathrm{mL}$ RNase in $2 x S S C$ buffer ( $0.3 \mathrm{M}$ sodium chloride; $0.03 \mathrm{M}$ sodium citrate) and incubated in humid chamber for $1 \mathrm{~h}$ at $37^{\circ} \mathrm{C}$. The slides were then immersed in $2 \times S S C$ twice at RT for 5 min, treated with $50 \mu \mathrm{L}$ of $10 \mathrm{mM} \mathrm{HCl}$ for $5 \mathrm{~min}$, then added $50 \mu \mathrm{L}$ of $10 \mathrm{mg} / \mathrm{mL}$ pepsin solution and $10 \mathrm{mM}$ $\mathrm{HCl}(1: 100 v / \mathrm{v})$, then the slides were incubated in humid chamber for $20 \mathrm{~min}$ at $37^{\circ} \mathrm{C}$. Later, the slides were washed in $2 \mathrm{xSSC}$ twice at room temperature for $5 \mathrm{~min}$, immersed in $4 \%$ formaldehyde at room temperature for $10 \mathrm{~min}$, and washed twice in $2 \mathrm{xSSC}$ for $5 \mathrm{~min}$. The dehydration step was performed in $70 \%$ ethanol and $96 \%$ ethanol, 5 min each. After drying the slides at room temperature for $30 \mathrm{~min}$, the hybridization mix with final volume of $15 \mu \mathrm{l}$ was added, containing $50 \%$ formamide, $10 \%$ dextran sulphate, 2xSSC (salt, sodium citrate; Sigma), 0.13\% sodium dodecyl sulphate (Bioagency) and $50 \mathrm{ng}$ of DNA probe. The hybridization mix was heated 
to $75^{\circ} \mathrm{C}$ for $10 \mathrm{~min}$ in thermocycler (Eppendorf, Mastercycler) and immediately transferred to ice for $5 \mathrm{~min}$. The slides containing the hybridization mix were denatured in thermocycler (Techne, TC-412), containing a slide adapter, at $75^{\circ} \mathrm{C}$ for $10 \mathrm{~min}$ and incubated overnight in humid chamber at $37^{\circ} \mathrm{C}$. After hybridization, the slides were immersed in $2 \mathrm{xSSC}$ at room temperature for $5 \mathrm{~min}$ to remove the cover slips. The slides were incubated in water bath (Marconi, MA093/1/E) at $42^{\circ} \mathrm{C}$, in 2 xSSC twice for $5 \mathrm{~min}$, in $0.1 \mathrm{xSSC}$ twice for $5 \mathrm{~min}$, and in $2 \mathrm{xSSC}$ twice for $5 \mathrm{~min}$. The slides were immersed in solution with $0.2 \% 4 \mathrm{xSSC} / \mathrm{Tween} 20$ (Sigma) for $5 \mathrm{~min}$ at room temperature, and treated with $50 \mu \mathrm{l}$ of $5 \%$ bovine serum albumin, fraction V (BSA; Sigma). The probes marked with biotin-16-dUTP were detected with $0.7 \mu \mathrm{l}$ avidina-fluorescein isothiocyanate (FITC-Avidin; Vector) plus $19.3 \mu \mathrm{l}$ of $5 \%$ BSA per slide. The probes marked with digoxigenin-11-dUTP were detected with $0.7 \mu \mathrm{l}$ anti-digoxigenin-rhodamine (Roche) plus $19.3 \mu \mathrm{l}$ of $5 \%$ BSA per slide. The slides containing the antibodies for detection were incubated in humid chamber for $1 \mathrm{~h}$ at $37^{\circ} \mathrm{C}$. To remove the antibody excess were performed three 5 -min rinses with $0.2 \% 4 \mathrm{xSSC} / \mathrm{Tween} 20$ at room temperature. The slides were briefly immersed in 2xSSC and simultaneously assembled and counter-stained with Vectashield Antifade Mounting Medium with DAPI $(\mathrm{H}-1200)$. The slides were then stored at $8-10^{\circ} \mathrm{C}$ until analysis.

\section{FISH analysis and photo-documentation}

The hybridization analysis and the photo-documentation were performed with the use of an epifluorescence microscope Olympus BX41 equipped with 5MP digital camera Olympus DP25 and DP2-BSW software. DAPI was visualized with U-MWU filter $(330-385 \mathrm{~nm}$ excitation / $400 \mathrm{~nm}$ dichroic cut-off / emission $>420 \mathrm{~nm}$ ). The hybridizations detected with avidin-FITC were visualized with the U-MWB filter (450-480 nm excitation / $500 \mathrm{~nm}$ dichroic cut-off / emission $>515 \mathrm{~nm}$ ) and the hybridizations detected with anti-digoxigenin-rhodamine were visualized with the U-MWG filter $(510-550 \mathrm{~nm}$ excitation / $570 \mathrm{~nm}$ dichroic cut-off / emission >590 nm). The overlaps of Rhodamine/DAPI for satellites and FITC/ DAPI for retroelements were performed with the use of Photoshop SC5 software.

\section{Endnotes}

${ }^{1}$ The site of the plant repeat database was decommissioned on February 8, 2017 due to the lack of sufficient funding in February 2017.
FISH: Fluorescent In Situ Hybridizations; gag genes: Group-specific antigen; IBGE: Brazilian Institute of Geography and Statistics; IGS: Large intergenic spacers; INT: Protein integrase; ITS: Internal transcribed spacers; LTR: Long Terminal Repeat; NCBI: National Center for Biotechnology Information; NGS: Next-Generation Sequencing; NTS: Non-transcribed spacer; P: Pair completeness index; PeSat: Satellite DNA Passiflora edulis; pol genes: Polyprotein; rDNA: ribosomal DNA; RT: Reverse transcriptase; SatDNA: Satellite DNA; TAREAN: Tandem Repeat Analyzer; TEs: Transposable elements; UESC: State University of Santa Cruz

\section{Acknowledgements}

The authors gratefully acknowledge the State University of Santa Cruz (UESC) for the infrastructure of the plant-breeding laboratory (LAMEP), where were made molecular cytogenetics preparations; the Center for Biotechnology and Genetics (CBG), where the Next-Generation Sequencing (NGS) was held; and the Center for Computational Biology and Biotechnology Information Management (NBCGIB), where were performed the bioinformatics analyses. The Federal Institute for Education, Science and Technology (IF Baiano) for the grant of training license to Vanessa de Carvalho Cayres Pamponét. The authors are also thankful to Dr. Jiri Macas for the valuable guidelines to use the RepeatExplorer pipeline.

\section{Funding}

The authors gratefully acknowledge financial support from the Coordination for Higher Level Personal Improvement (CAPES), the National Council for Scientific and Technological Development (CNPq) and the Foundation for Support to Research of the Bahia State (FAPESB) in design of the study and collection, analysis, and interpretation of data and in writing the manuscript. The authors would also like to thank the CNPq for the scholarship awarded to Margarete Magalhães Souza, the FAPESB for the scholarships granted to the students Gonçalo Santos Silva and CAPES for the scholarships granted to Cláusio Antônio Ferreira de Melo.

\section{Availability of data and materials}

Additional annotations of the genomic locus of Satellite DNAs and LTR retrotransposons $\mathrm{s}$ according to the current study were submitted and are available in the GeneBank repository NCBI (https://www.ncbi.nlm.nih.gov/ nuccore/) under the accession codes MF401643, MF401645, MF401644, MF401635, MF401636, MF401639, MF401642, MF401640, MF401637 and MF401638. Other datasets generated during and/or analyzed during the current study available from the corresponding author on reasonable request.

\section{Authors' contributions}

VCCP, MMS, GSS, FM, CAFM and RXC conceived of the study and designed the experiments; VCCP, GSS, FM, SGO, EAC performed the experiments and analyzed data; VCCP wrote the manuscript. All authors read and approved the final manuscript.

\section{Ethics approval and consent to participate}

Considering that this work has not been carried out with transgenic plants, UESC does not require consent for research with plant material. Source: Stakes collected from the commercial populations of passion fruit-producing farms in the municipality of Livramento de Nossa Senhora, Bahia State (BA), Brazil. It was not necessary the field permission to collect the samples, since they were donated by the producers. The specimens were not deposited as a voucher because of the commercial population. We declare that we are acting in accordance with local law.

\section{Consent for publication}

Not applicable

\section{Competing interests}

The authors declare that they have no competing interests.

\section{Publisher's Note}

Springer Nature remains neutral with regard to jurisdictional claims in published maps and institutional affiliations.

\footnotetext{
Abbreviations

BA: Bahia State; BAG: Germplasm Active Bank; C: Connected component index; CBG: Center of Biotechnology and Genetics; Chip: Chromatin immunoprecipitation; Chip-seq: Chip sequencing; CLs: Clusters;
} 


\section{Author details}

'Departamento de Ciências Biológicas, Universidade Estadual de Santa Cruz (UESC), km 16, Salobrinho, Ihéus, Bahia CEP 45662-900, Brazil. ${ }^{2}$ CIRAD, UMR AGAP, F-34398 Montpellier, France. ${ }^{3}$ Departamento de Botânica, Instituto de Biociências, Universidade de São Paulo (USP), Rua do Matão, 14 - Butantã, São Paulo, SP CEP 05508-090, Brazil. ${ }^{4}$ Núcleo de Biologia Computacional e Gestão de Informações Biotecnológicas (NBCGIB), Universidade Estadual de Santa Cruz (UESC), km 16, Salobrinho, Ilhéus, Bahia CEP 45662-900, Brazil.

Received: 13 March 2018 Accepted: 28 February 2019 Published online: 02 April 2019

\section{References}

1. Ferreira FR. Germoplasma de Passiflora no Brasil. In: São José AR, editor. Maracujá: Produção e Mercado. Vitória da Conquista: UESB, 1994. p. 24-26.

2. Bernacci LC, Soares-Scott MD, Junqueira NTV, Passos IRS, Meletti LMM. Passiflora edulis Sims: the correct taxonomic way to cite the yellow passion fruit (and of others colors). Rev Bras Frutic. 2008;30:566-76.

3. Bernacci LC, Cervi AC, Milward-de-Azevedo MA, Nunes TS, Imig DC, Mezzonato AC. Passifloraceae. In: Lista de Espécies da Flora do Brasil. Jardim Botânico do Rio de Janeiro. 2013. http://floradobrasil.jbrj.gov.br/jabot/ floradobrasil/FB128567. Accessed 6 Aug 2017.

4. Pires MM, Mata HTC. Uma abordagem econômica e mercadológica para a cultura do maracujá no Brasil. In: Lima AA, Cunha MAP, editors. Maracujá: Produção e Qualidade na Passicultura. Cruz das Almas: EMBRAPA Mandioca e Fruticultura; 2004. p. 323-343.

5. Pires MM, Gomes AS, Midlej MMBC, São José AR, Rosado PL, Passos HDB. Caracterização do mercado de maracujá. In: Pires MM, São José AR, Conceição AO, editors. Maracujá: Avanços Tecnológicos e Sustentabilidade. Ihéus: Editus; 2011. p. 21-67.

6. IBGE - Instituto Brasileiro de Geografia e Estatistica. Produção Agrícola Municipal: Culturas temporárias permanentes 2015. http://biblioteca.ibge. gov.br/index.php/biblioteca-catalogo?view=detalhes\&id=766 (2016). Accessed 20 Aug 2017.

7. Li W, Zhang P, Fellers JP, Friebe B, Gill BS. Sequence composition, organization, and evolution of the core Triticeae genome. Plant J. 2004. https://doi.org/10.1111/j.1365-313X.2004.02228.x.

8. Mehrotra S, Goyal V. Repetitive sequences in plant nuclear DNA: types, distribution, evolution and function. Genomics, Proteomics e Bioinformatics. 2014; doi:https://doi.org/10.1016/j.gpb.2014.07.003.

9. Sharma S, Raina SN. Organization and evolution of highly repeated satellite DNA sequences in plant chromossomes. Cytogenetic and Genome Research. 2005. https://doi.org/10.1159/000082377.

10. Jurka J, Kapitonov W, Kohany O, Jurka MV. Repetitive sequences in complexe genomes; structure and evolution. Annu Rev Genomics Hum Genet. 2007. https://doi.org/10.1146/annurev.genom.8.080706.092416.

11. López-Flores I, Garrido-Ramos MA. The repetitive DNA content of eukaryotic genomes. In: Garrido-Ramos MA, editor. Repetitive DNA, Genome Dyn, Basel: Karger Publishers; 2012. p. 1-28.

12. Rao SR, Trivedi S, Emmanuel D, Merita K, Hynniewta M. DNA repetitive sequence-types, distribution and function: A review. Journal of Cell and Molecular Biology. 2010;7(2) \& 8(1)):1-11.

13. Heslop-Harrison JS. Comparative genome organization in plants: from sequence and markers to chromatin and chromosomes. Plant Cell. 2000;12:617-35.

14. McClintock B. Mutable loci in maize. Carnegie Institution of Washington: Year book; 1948. p. 155-169.

15. Kapitonov W, Jurka J. Rolling-circle transposons in eukaryotes. Proc Natl Acad Sci U S A. 2001;98:8714-9.

16. Wicker T, Sabot F, Hua-Van A, Bennetzen JL, Capy P, Chalhoub B, Flavell A, Leroy P, Morgante M, Panaud O, Paux E, SanMiguel P, Schulman AH. A unified classification system for eukaryotic transposable elements. Nat Rev Genet. 2007. https://doi.org/10.1038/nrg2165.

17. Eickbush $\mathrm{TH}$, Jamburuthugoda VK. The diversity of retrotransposons and the properties of their reverse transcriptases. Virus Res. 2008. https://doi.org/10. 1016/j.virusres.2007.12.010.

18. Bennetzen $\mathrm{J}$, Wang $\mathrm{H}$. The contributions of transposable elements to the structure, function, and evolution of plant genomes. Annu Rev Plant Biol. 2014;65:505-30.

19. Grandbastien MA. LTR-retrotransposons, handy hitchhikers of plant regulation and stress response. Biochim Biophys Acta. 2015. https://doi.org/ 10.1016/j.bbagrm.2014.07.017.
20. Hua-Van A, Le Rouzic A, Boutin TS, Filée J, Capy P. The struggle for life of the genome's selfish architects. Biol Direct. 2011;6:19.

21. Carareto CMA, Monteiro-Vitorello CB, Sluys MV. Elementos de Transposição - diversidade, evolução, aplicações e impacto nos genomas dos seres vivos. In: Varani AM, Carvalho LCB, Zerillo MM, Monteiro-Vitorello CB, editors. Elementos de transposição: classificação e mecansismos de mobilização. Rio de Janeiro: Fiocruz; 2015. p. 11-42.

22. Cheng Z, Dong F, Langdon T, Ouyang S, Buell CR, Gu M, Blattner FR, Jiang J. Functional rice centromeres are marked by a satellite and a centromerespecific retrotransposon. Plant Cell. 2002;14:1691-704.

23. Liu Z, Yue W, Li D, Wang R, Kong X, Lu K, Wang G, Dong Y, Jin W, Zhang X. Structure and dynamics of retrotransposons at wheat centromeres and pericentromeres. Chromossoma. 2008. https://doi.org/10.1007/s00412-0080161-9.

24. Bao W, Zhang W, Yang Q, Zhang Y, Han B, Gu M, Xue Y, Cheng Z. Diversity of centromeric repeats in two closely related wild Rice species, Oryza officinalis and Oryza rhizomatis. Mol Gen Genomics. 2006. https://doi.org/10. 1007/s00438-006-0103-2.

25. Nagaki K, Song J, Stupar RM, Parokonny AS, Yuan Q, Ouyang S, Liu J, Hsiao J, Jones KM, Dawe RK, Buell CR, Jiang J. Molecular and cytological analyses of large tracks of centromeric DNA reveal the structure and evolutionary dynamics of maize centromeres. Genetics. 2003;163(2):759-70.

26. Deragon JM, Capy P. Impact of transposable elements on the human genome. Ann Med. 2000;32:264-73.

27. Ziemniczak A, Traldi JB, Nogaroto V, Almeida MC, Artoni RF, Moreira-Filho O, Vicari MR. In situ localization of (GATA) $n$ and (TTAGGG) $n$ repeated DNAs and W sex chromosome differentiation in Parodontidae (Actinopterygii: Characiformes). Cytogenet Genome Res. 2015. https://doi.org/10.1159/ 000370297.

28. Shapiro JA, Von Sternberg R. Why repetitive DNA is essential to genome function. Biol Rev. 2005;80:227-50.

29. Zwick MS, Islam-Faridi MN, Zhang HB, Hodnett GL, Gomez MI, Kim JS, Price $\mathrm{HJ}$, Stelly DM. Distribution and sequence analysis of the centromereassociated repetitive element CEN38 of Sorghum bicolor (Poaceae). Am J Bot. 2000;87:1757-64.

30. Berthelier J, Casse N, Daccord N, Jamilloux V, Saint-Jean B, Carrier G. A transposable element annotation pipeline and expression analysis reveal potentially active elements in the microalga Tisochrysis lutea. BMC Genomics. 2018;19(1):378.

31. Santos AA, Penha HA, Bellec A, Munhoz CF, Pedrosa-Harand A, Bergès H, Vieira MLC. Begin at the beginning: a BAC-end view of the passion fruit (Passiflora) genome. BMC Genomics. 2014. https://doi.org/10.1186/1471-2164-15-816.

32. Silva MGM, Viana AP, Amaral Júnior AT do, Gonçalves LSA, Reis RV. Biometria aplicada ao melhoramento intrapopulacional do maracujazeiro amarelo. Rev Ciênc Agron 2012; 43:134-140.

33. Ohmido N, Akiyama Y, Fukui K. Physical mapping of unique nucleotide sequences on identified Rice chromosomes. Plant Mol Biol. 1998;6:1043-52.

34. Zhou S, De Jeu MJ, Visser RGF, Kuipers AG. Characterization of distant Alstroemeria hybrids: application of highly repetitive DNA sequences from A ligtu ssp ligtu. Annals of Applied Biology. 2003. https://doi.org/10.1111/j. 1744-7348.2003.tb00251.x.

35. Bernacci LC, Meletti LMM, Soares-Scott MD, Passos IRS, Junqueira NTV. Espécies de maracujá: caracterização e conservação da biodiversidade. In: Faleiro FG, Junqueira NTV, Braga MF, Editors. Maracujá: germoplasma e melhoramento genético. Planaltina- DF: Embrapa Cerrados, 2005. p.559-586.

36. Soares-Scott MD, Meletti LMM, Bernacci LC, Passos IRS. Citogenética clássica e molecular em passifloras. In: Faleiro FG, Junqueira NTV, Braga MF, editors. Maracujá, Germoplasma e Melhoramento Genético. Planaltina: Embrapa Cerrados; 2005. p. 213-40.

37. Carneiro MS, Camargo LEA, Coelho ASG, Venkovsky R, Leite RP, Stenzel NM, Vieira MLC. RAPD-based genetic linkage maps of yellow passion fruit (Passiflora edulis Sims. f. flavicarpa Deg.). Genome. 2002;45:670-8.

38. Oliveira EJ, Vieira MLC, Garcia AAF, Munhoz CF, Margarido GRA, Consoli L, Matta FP, Moraes MC, Zucchi MI, Fungaro MHP. An integrated molecular map yellow passion fruit based on simultaneous maximum-likelihood estimation of linkage and linkage phases. Journal of the American Society Horticultural Science. 2008;133(1):35-41.

39. Ohmido N, Ishimaru A, Kato S, Sato S, Tabata S, Fukui K. Integration of cytogenetic and genetic linkage maps of Lotus japonicus, a model plant for legumes. Chromossome Research. 2010. https://doi.org/10.1007/s10577009-9103-5. 
40. Talbert PB. Adaptive evolution of centromere proteins in plants and animals. J Biol. 2004. https://doi.org/10.1186/jbiol11.

41. Birchler JA, Han F. Maize centromeres: structure, function, epigenetics. Annu Rev Genet. 2009. https://doi.org/10.1146/annurev-genet-102108-134834.

42. Novák P, Neumann P, Pech J, Steinhaisl J, Macas J. RepeatExplorer: a Galaxybased web server for genome wide characterization of eukaryotic repetitive elements from next generation sequence reads. Bioinformatics. 2013. https://doi.org/10.1093/bioinformatics/btt054.

43. Novák P, Neumann P, Macas J. Principle of clustering analysis: graph based clustering and characterization of repetitive sequences in next generation sequencing data. BMC Bioinformatics. 2010. https://doi.org/10.1186/14712105-11-378.

44. Sousa A, Bellot S, Fuchs J, Houben A, Renner SS. Analysis of transposable elements and organellar DNA in male and female genomes of a species with a huge $Y$ chromosome reveals distinct $Y$ centromeres. Plant J. 2016. https://doi.org/10.1111/tpj.13254.

45. Novák P, Hřibová E, Neumann P, Kobližková A, Doležel J, Macas J. Genomewide analysis of repeat diversity across the family Musaceae. PLoS One. 2014. https://doi.org/10.1371/journal.pone.0098918.

46. Novák P, Robledillo LA, Koblízková A, Vrbová I, Neumann P, Macas J. TAREAN: a computacional tool for idenfication and characterization of satellite DNA from unassembled short reads. Nucleic Acids Research. 2017 https://doi.org/10.1093/nar/gkx257.

47. Macas J, Kejnovský E, Neumann P, Novák P, Kobližková A, Vyskot B. Next generation sequencing-based analysis of repetitive DNA in the model Dioceous plant Silene latifolia. PLoS One. 2011. https://doi.org/10.1371/ journal.pone.0027335.

48. Macas J, Novák P, Pellicer J, Čižková J, Koblížková A, Neumann P, Fuková I, Doležel J, Kelly LJ, Leitch LJ. In Depth Characterization of Repetitive DNA in 23 Plant Genomes Reveals Sources of Genome Size Variation in the Legume Tribe Fabeae. PLOS ONE. 2015. https://doi.org/10.1371/journal.pone.0143424.

49. SanMiguel $P$, Bennetzen $J$. Evidence that a recent increase in maize genome size was caused by the massive amplification of intergene retrotranposons. Ann Bot. 1998. https://doi.org/10.1006/anbo.1998.0746.

50. Křivánková A, Kopecký D, Stočes Š, Doležel J, Hřibová E. Repetitive DNA: a versatile tool for karyotyping in Feestuca pratensis Huds. Cytogenetic and Genome Research. 2017;151:96-105.

51. Paz RC, Kozaczek ME, Rosl HG, Andino NP, Sanchez-Puerta MV. Diversity, distribution and dynamics of full-length Copia and gypsy LTR retroelements in Solanum lycopersicum. Genetica. 2017;145:417-30.

52. Qiu F, Ungerer MC. Genomic abundance and transcriptional activity of diverse gypsy and copia long terminal repeat retrotransposons in three wild sunflower species. BMC Plant Biol. 2018. https://doi.org/10.1186/s12870-017-1223-z.

53. de Souza TB, Chaluvadi SR, Johnen L, Marques A, González-Elizondo MS, Bennetzen JL, ALL V. Analysis of retrotransposon abundance, diversity and distribution in holocentric Eleocharis (Cyperaceae) genomes. Annals of Botany. 2018. https://doi.org/10.1093/aob/mcy066.

54. Gottlob-McHugh SG, Lévesque M, MacKenzie K, Olson M, Yarosh O, Johnson DA. Organization of the $5 S$ rDNA genes in the soybean Glycine max (L.) Merrill and conservation of the $5 \mathrm{~S}$ rDNA repeat structure in higher plants. Genome. 1990:33:486-94.

55. Cronn R, Zhao X, Paterson AH, Wendel JF. Polymorphism and concerted evolution in a tandemly repeated gene family: $5 \mathrm{~S}$ ribosomal DNA in diploid and allopolyploid cottons. J Mol Evol. 1996. https://doi.org/10.1007/ BF02338802

56. Kellogg EA, Appels R. Intraspecific and interspecific variation in 5S RNA genes are decoupled in diploid wheat relatives. Genetics. 1995;140(1):325-43.

57. Maughan P, Kolano BA, Maluszynska J, Coles ND, Bonifacio A, Rojas J, Coleman CE, Stevens MR, Fairbanks DJ, Parkinson SE, Jellen EN. Molecular and cytological characterization of ribosomal RNA genes in Chenopodium quinoa and Chenopodium berlandieri. Genome. 2006. https://doi.org/10. 1139/G06-033.

58. Lan T, Albert VA. Dynamic distribution patterns of ribosomal DNA and chromosomal evolution in Paphiopedilum, a lady's slipper orchid. BMC Plant bio. 2011. https://doi.org/10.1186/1471-2229-11-126.

59. Plohl M, Mestrovic N, Mravinac B. Centromere identity from the DNA point of view. Chromossoma. 2014. https://doi.org/10.1007/s00412-014-0462-0.

60. Nunes RC, Orozco-Arias S, Crouzillat D, Mueller LA, Strickler SR, Descombes P, Fournier C, Moine D, Kochko A, Yuyama PM, Vanzela ALL, Guyot R. Structure and distribution of Centromeric retrotransposons at diploid and
Allotetraploid Coffea Centromeric and Pericentromeric regions. Front Plant Sci. 2018. https://doi.org/10.3389/fpls.2018.00175.

61. Gong Z, Wu Y, Kobližková A, Torres GA, Wang K, lovene M, Neumann P, Zhang W, Novák P, Buell CR, Macas J, Jiang J. Repeatless and repeat-based centromeres in potato: implications for centromere evolution. Plant Cell. 2012;24:3559-74.

62. Zhang W, Zuo S, Li Z, Meng Z, Han J, Song J, et al. Isolation and characterization of centromeric repetitive DNA sequences in Saccharum spontaneum. Sci Rep. 2017;7:41659. https://doi.org/10.1038/srep41659.

63. Park PJ. ChIP-Seq: advantages and challenges of a maturing technology. Nat Rev Genet. 2009. https://doi.org/10.1038/nrg2641.

64. Torres GA, Gong Z, lovene M, Hirsch CD, Buell CR, Bryan GJ, Novák P, Macas J, Jiang J, Birchler JA. Organization and evolution of subtelomeric satellite repeats in the potato genome. G3: Genes, Genomes, Genetics. 2011. https:// doi.org/10.1534/g3.111.000125.

65. Cheng Z, Stupar RM, Gu M, Jiang J. A tandemly repeated DNA sequence is associated with both knob-like heterochromatin and a highly decondesed structure in the meiotic pachytene chromossomes of rice. Chromosoma. 2001. https://doi.org/10.1007/s004120000126.

66. Li J, Yang F, Zhu J, He S, Li L. Characterization of tandemly repeated subtelomeric sequence with inverted telomere repeats in maize. Genome. 2009. https://doi.org/10.1139/G09-005.

67. Macas J, Navrtilová A, Mészáros T. Sequences subfamilies of satellites repeats related to rDNA intergenic spacer are differentially amplified on Vicia sativa chromosomes. Chromosoma. 2003. https://doi.org/10.1007/ s00412-003-0255-3.

68. Nuvikova O. Chromodomains and LTR retrotransposons in plants. Comm e Integr Biol. 2009;2:158-62.

69. Lippman Z, Gendrel AV, Black M, Vaughn MW, Dedhia N, Mccombie WR, Lavine K, Mittal V, May B, Kaschau KD, Carrington JC, Doerge RW, Colot V, Martienssen R. Role of transposable elements in heterochromatin and and epigenetic control. Nature. 2004. https://doi.org/10.1038/nature02651.

70. Zhong CX, Marshall JB, Topp C, Mroczek R, Kato A, Nagaki K, Birchler JA, Jiang JM, Dawe RK. Centromeric retroelements and satellites interact with maize kinetochore protein CENH3. Plant Cell. 2002. https://doi.org/10.1105/ tpc.006106.

71. Puterova J, Razumova O, Martinek T, Alexandrov O, Divashuk M, Kubat Z, Hobza R, Karlov G, Kejnovsky E. Satellite DNA and transposable elements is Seabuckthorn (Hippophae rhamnoides), a dioecious plant with small $Y$ and large X chromosomes. Genome Biology and Evolution. 2017. https://doi. org/10.1093/gbe/evw303.

72. Johansen DA. Plant microtechnique. New York: Mcgraw-Hill Book; 1940.

73. Doyle JJ, Doyle JL. Isolation of plant DNA from fresh tissue. Focus. 1990; 12(1):13-5.

74. Viana AJC, Souza MM, Araújo IS, Corrêa RX, Ahnert D. Genetic diversity in Passiflora species determined by morphological and molecular characteristics. Biol Plant. 2010;54:535-8.

75. Souza MM, Palomino G, Pereira TNS, Pereira MG, Viana AP. Flow cytometric analysis of genome size variations in some Passiflora species. Hereditas. 2004. https://doi.org/10.1111/j.1601-5223.2004.01739.x.

76. Dereeper A, Guignon V, Blanc G, Audic S, Buffet S, Chevenet F, Dufayard JF, Guindon S, Lefort V, Lescot M, Claverie JM, Gascuel O. Phylogeny.fr: robust phylogenetic analysis for the non-specialist. Nucleic Acids Res. 2008. https:// doi.org/10.1093/nar/gkn180.

77. Edgar RC. MUSCLE: multiple sequence alignment with high accuracy and high throughput. Nucleic Acids Res. 2004. https://doi.org/10.1093/nar/ gkh340.

78. Untergasser A, Nijveen H, Rao X, Bisseling T, Geurts R, Leunissen AMJ. Primer3Plus, an enhanced web interface to Primer3. Nucleic Acids Research. 2007. https://doi.org/10.1093/nar/gkm306.

79. Schwarzacher T, Heslop-Harrison P. Practical in situ hybridization. Oxford: Bios Scientific Publishers; 2000.

80. Souza MM, Urdampilleta JD, Forni-Martins ER. Improvements in cytological preparations for fluorescent in situ hybridization in Passiflora. Genet Mol Res. 2010. https://doi.org/10.4238/vol9-4gmr951.

81. Melo CAF, Silva GS, Souza MM. Establishment of genomic in situ hybridization (GISH) technique for analysis in interspecific hybrids of Passiflora. Genet Mol Res. 2015;14:2176-88. 